Article

\title{
Hydrogen Sulfide Relaxes Human Uterine Artery via Activating Smooth Muscle BK $\mathrm{Ca}$ Channels
}

\author{
Yan Li ${ }^{1}$, Jin Bai ${ }^{1} \oplus$, Yi-hua Yang ${ }^{1}$, Naoto Hoshi ${ }^{2}$ and Dong-bao Chen ${ }^{1, *}$ \\ 1 Department of Obstetrics \& Gynecology, University of California, Irvine, CA 92697, USA; \\ liy60@hs.uci.edu (Y.L.); baij3@hs.uci.edu (J.B.); yangyihua@gxmu.edu.cn (Y.-h.Y.) \\ 2 Department of Pharmacology, University of California, Irvine, CA 92697, USA; nhoshi@uci.edu \\ * Correspondence: dongbaoc@uci.edu; Tel.: +1-949-824-2409
}

Received: 16 September 2020; Accepted: 6 November 2020; Published: 13 November 2020

\begin{abstract}
Opening of large conductance calcium-activated and voltage-dependent potassium $\left(\mathrm{BK}_{\mathrm{Ca}}\right)$ channels hyperpolarizes plasma membranes of smooth muscle (SM) to cause vasodilation, underling a key mechanism for mediating uterine artery (UA) dilation in pregnancy. Hydrogen sulfide $\left(\mathrm{H}_{2} \mathrm{~S}\right)$ has been recently identified as a new UA vasodilator, yet the mechanism underlying $\mathrm{H}_{2} \mathrm{~S}$-induced UA dilation is unknown. Here, we tested whether $\mathrm{H}_{2} \mathrm{~S}$ activated $\mathrm{BK}_{\mathrm{Ca}}$ channels in human UA smooth muscle cells (hUASMC) to mediate UA relaxation. Multiple $\mathrm{BK}_{\mathrm{Ca}}$ subunits were found in human UA in vitro and hUASMC in vitro, and high $\beta 1$ and $\gamma 1$ proteins were localized in SM cells in human UA. Baseline outward currents, recorded by whole-cell and single-channel patch clamps, were significantly inhibited by specific $\mathrm{BK}_{\mathrm{Ca}}$ blockers iberiotoxin (IBTX) or tetraethylammonium, showing specific $\mathrm{BK}_{\mathrm{Ca}}$ activity in hUASMC. $\mathrm{H}_{2} \mathrm{~S}$ dose $(\mathrm{NaHS}, 1-1000 \mu \mathrm{M})$-dependently potentiated $\mathrm{BK}_{\mathrm{Ca}}$ currents and open probability. Co-incubation with a $\mathrm{Ca}^{2+}$ blocker nifedipine $(5 \mu \mathrm{M})$ or a chelator (ethylene glycol-bis ( $\beta$-aminoethyl ether)- $\mathrm{N}, \mathrm{N}, \mathrm{N}^{\prime}, \mathrm{N}^{\prime}$-tetraacetic acid (EGTA), $5 \mathrm{mM}$ ) did not alter $\mathrm{H}_{2} \mathrm{~S}$-potentiated $\mathrm{BK}_{\mathrm{Ca}}$ currents and open probability. NaHS also dose-dependently relaxed phenylephrine pre-constricted freshly prepared human UA rings, which was inhibited by IBTX. Thus, $\mathrm{H}_{2} \mathrm{~S}$ stimulated human UA relaxation at least partially via activating $\mathrm{SM} \mathrm{BK}_{\mathrm{Ca}}$ channels independent of extracellular $\mathrm{Ca}^{2+}$.
\end{abstract}

Keywords: hydrogen sulfide; $\mathrm{BK}_{\mathrm{Ca}}$ channels; smooth muscle; uterine artery; women

\section{Introduction}

Normal pregnancy is associated with dramatically increased uterine perfusion, reflected by as high as 20-80-fold rises in uterine blood flow in the third trimester in a singleton pregnant woman [1]. Pregnancy-associated uterine vasodilation is rate-limiting for pregnancy health since rise in uterine blood flow delivers nutrients and $\mathrm{O}_{2}$ from the mother to fetus and exhausting $\mathrm{CO}_{2}$ and metabolic wastes from the fetus to mother, mandatory to support fetal development and survival. Constrained uterine blood flow has been implicated in preeclampsia, intrauterine growth restriction, and other pregnancy diseases [2,3], not only raising the morbidity and mortality of the fetus and the mother during pregnancy, but also predisposing them more susceptible to cardiovascular and other metabolic disorders later in life $[4,5]$.

The mechanisms underlying pregnancy-associated uterine vasodilation are complex and incompletely understood; however, compelling evidence has pinpointed down a key role of locally produced vasodilators in relaxing the uterine artery (UA) smooth muscle (SM). Many vasodilators have been identified to play a role in mediating uterine vasodilation, with prostacyclin and nitric oxide as the most studied forms [6-8]. However, systemic inhibition of prostaglandin synthesis by indomethacin does not result in concurrent systemic or uteroplacental vasoconstriction, suggesting that uterine blood flow is not directly dependent on maintained prostaglandin synthesis [9]. Local UA NO 
inhibition also only modestly $(\approx 26 \%)$ inhibits baseline pregnancy-associated uterine vasodilation [10]. These studies clearly suggest that additional mechanisms are involved to mediate pregnancy-associated uterine vasodilation.

More recently, we have reported that pregnancy augments UA production of hydrogen sulfide $\left(\mathrm{H}_{2} \mathrm{~S}\right)$ in ewes [11] and women [12]. $\mathrm{H}_{2} \mathrm{~S}$ has being widely accepted as the third gaseous signaling molecule of the "gasotransmitter" family that also includes nitric oxide and carbon monoxide, which exert similar pluripotent biological functions throughout the body [13]. Endogenous $\mathrm{H}_{2} \mathrm{~S}$ is mainly synthesized by metabolizing L-cysteine via two specific enzymes, cystathionine- $\beta$-synthase (CBS) and cystathionine- $\gamma$ lyase (CSE) [14]. Systemic vasculature produces $\mathrm{H}_{2} \mathrm{~S}$ mainly via upregulating endothelial cell (EC) CSE expression or activity, which is a potent physiological vasorelaxant [15] and proangiogenic factor [16] as well as an antioxidant [13]. However, $\mathrm{UA} \mathrm{H}_{2} \mathrm{~S}$ production is associated with SM and EC CBS upregulation, without altering CSE expression, during pregnancy in vivo [11,12] and in cultured human UA EC in vitro [17], demonstrating that CBS is the key enzyme responsible for $\mathrm{UA}_{2} \mathrm{~S}$ production during pregnancy. We have also shown that a slow releasing $\mathrm{H}_{2} \mathrm{~S}$ donor GYY4137 dose-dependently induces pregnancy-dependent UA relaxation in rats in vitro [12], suggesting that $\mathrm{H}_{2} \mathrm{~S}$ functions as a "new" uterine vasodilator. However, how $\mathrm{H}_{2} \mathrm{~S}$ dilates UA is currently unknown.

Activation of the ATP-sensitive potassium $\left(\mathrm{K}_{\mathrm{ATP}}\right)$ channels was the first mechanism demonstrated to mediate $\mathrm{H}_{2} \mathrm{~S}$-induced rat mesentery and aortic vasodilation [18,19]. However, local infusion of the $\mathrm{K}_{\text {ATP }}$ channel blocker glibenclamide does not significantly affect baseline pregnancy-associated uterine vasodilation [20]. Activation of endothelial large conductance $\mathrm{Ca}^{2+}$-activated voltage-dependent potassium $\left(\mathrm{BK}_{\mathrm{Ca}}\right)$ channels also plays a role in mediating $\mathrm{H}_{2} \mathrm{~S}$-induced vasodilation in rat mesenteric arteries [21]. $\mathrm{BK}_{\mathrm{Ca}}$ channels are tetramer formed by the pore-forming $\alpha$ subunit along with regulatory 31-4 and $\gamma$ 1-4 subunits, which can lead to the enormous diversity in channel function [22,23]. The channel complex is activated by membrane depolarization and/or increased intracellular $\mathrm{Ca}^{2+}$. Opening of the channel allows $\mathrm{K}^{+}$efflux leading to hyperpolarization, whereas closure of the channel causes depolarization. The activity of $\mathrm{BK}_{\mathrm{Ca}}$ is critical in determining the membrane potential of vascular SM cells and hence vascular tone [24]. $\beta 1$ containing $\mathrm{BK}_{\mathrm{Ca}}$ channels are better characterized in SM cells, while $\gamma$ subunits is newly discovered to functionally and potently regulate $\mathrm{BK}_{\mathrm{Ca}}$ channel in vitro $[25,26]$. Pregnancy augments the expression of $\beta 1$ subunit; local infusion of the BK $\mathrm{Ca}_{\mathrm{C}}$ blocker tetraethylammonium (TEA) abolishes pregnancy-induced UA dilation in vitro [27] and inhibits uterine blood flow in vivo [28-30]. Pregnancy increases UA $\gamma 1$ subunit expression sevenfold and $\gamma 1$ subunit deficiency results in attenuation of pregnancy-augmented increase in $\mathrm{BK}_{\mathrm{Ca}}$ activity and UA dilation in mice [31]. Thus, $\mathrm{BK}_{\mathrm{Ca}}$ channels play a key role in uterine hemodynamics during pregnancy.

We hypothesized herein that activation of smooth muscle cell $\mathrm{BK}_{\mathrm{Ca}}$ channels mediates $\mathrm{H}_{2} \mathrm{~S}$-induced human UA dilation. The purpose of this study was to determine which $\mathrm{BK}_{\mathrm{Ca}}$ channel subunits are expressed in human UA and cultured primary human UA SM cells (hUASMC) in vivo, as well as using primary hUASMC in culture to test (1) whether functional $\mathrm{BK}_{\mathrm{Ca}}$ channels are present, and (2) whether $\mathrm{H}_{2} \mathrm{~S}$ modifies $\mathrm{BK}_{\mathrm{Ca}}$ channel activity, and if yes, by what mechanism(s). In addition, we used organ bath studies to determine if $\mathrm{BK}_{\mathrm{Ca}}$ channels mediate $\mathrm{H}_{2} \mathrm{~S}$-induced relaxation of pressurized human UA (hUA) in vitro.

\section{Materials and Methods}

\subsection{Ethics and Human Uterine Artery Collection}

The main uterine arteries were obtained from pregnant women in the event of hysterectomy at the University of California Irvine Medical Center. Written consent was obtained from all participants, and ethical approval (IRB\#2013-9763) was granted by the Institutional Review Board for Human Research at the University of California, Irvine. The tissues were collected from 5 pregnant women in an event of caesarean hysterectomy due to placenta accreta. The subjects were 26-44 years of age and at 33-37 weeks of gestation, without any other complications. The main uterine arteries were collected 
within $1 \mathrm{~h}$ after hysterectomy and placed in chilled culture medium and transported to the laboratory. Portions of each UA was allocated to be fixed in $4 \%$ paraformaldehyde or snap-frozen in liquid $\mathrm{N}_{2}$, and the rest was used for organ bath studies.

\subsection{Antibodies and Chemicals}

Anti-human $\beta$-actin monoclonal antibody (AM4302), anti-human $\mathrm{BK}_{\mathrm{Ca}} \gamma 1$ subunit (PA5-38058), Dulbecco's modified Eagle's medium (DMEM, 12800-017), Alexa ${ }^{488}$ donkey anti-mouse immunoglubin G (IgG), Alexa ${ }^{568}$ goat anti-mouse IgG, and mounting medium containing 4',6-diamidino-2phenylindole (DAPI, 2105716) were from Invitrogen (San Diego, CA, USA). Anti-human BK $\mathrm{Ca}_{\mathrm{C}}$ $\beta 1$ monoclonal antibody (sc-377023) was from Santa Cruz (Dallas, TX, USA). Anti-human BK $\mathrm{Ca}_{\mathrm{C}}$ $\gamma 3$ monoclonal antibody (ab121412) was from Abcam (Cambridge, MA, USA). Anti-human CD31 (M0823) was from Dako (Santa Clara, CA, USA). Phenylephrine was from Tocris (Bristol, United Kingdom). Sodium hydrosulfide (NaHS, 161527), iberiotoxin (IBTX, I5904), TEA, T2265, nifedipine (N7634), ethylene glycol-bis ( $\beta$-aminoethyl ether)- $\mathrm{N}, \mathrm{N}, \mathrm{N}^{\prime}, \mathrm{N}^{\prime}$-tetraacetic acid (EGTA), dithiothreitol (DTT), bovine serum albumin (BSA, A7906), fetal bovine serum (FBS, F6178), and all other chemicals were from Sigma (St. Louis, MO, USA), unless indicated.

\subsection{Isolation and Culture of Primary UA Smooth Muscle Cells (hUASMC)}

Fresh UA was washed at least 3 times with cold sterilized PBS. Connective tissues around the vessels were carefully removed and the lumen was flushed with ice-cold DMEM. After removal of EC by filling the lumen with $0.1 \%$ collagenase (type II) in phosphate-buffered saline (PBS) for 15 min at $37^{\circ} \mathrm{C}$, we cut the EC-denuded artery into $\approx 1 \mathrm{~cm}$ long rings and then soaked them in $0.05 \%$ collagenase for $20 \mathrm{~min}$. The smooth muscle was then mechanically separated under a $50 \times$ stereo microscopy. The isolated smooth muscle was minced and then digested with collagenase for $30-45 \mathrm{~min}$ at $37^{\circ} \mathrm{C}$. Fetal bovine serum (FBS, final concentration $=10 \%$ ) was added to terminate digestion. Single SM cells were collected and plated in $10 \mathrm{~cm}$ dishes and cultured in DMEM containing 10\% FBS and 1\% penicillin/streptomycin. After 7-day culture, hUASMC colonies were marked. Each colony was then picked up by using a cloning disc presoaked with $1 \%$ trypsin/EDTA as previously described [17]. Each colony was transferred into a well of a 12 -well plate and cultured until $\approx 90 \%$ density. The cells were then stored in liquid $\mathrm{N}_{2}$ for experimental use within 3 passages.

\subsection{Immunofluorescence Microscopy}

Sections $(6 \mu \mathrm{m})$ of paraffin-embedded UA rings were dehydrated and treated with proteinase $\mathrm{K}$ for antigen retrieval for $10 \mathrm{~min}$ at $37^{\circ} \mathrm{C}$, followed by rinsing 3 times with PBS. After incubation with $1 \%$ bovine serum albumin (BSA) in PBS to block nonspecific binding for $30 \mathrm{~min}$ at room temperature, the sections were incubated with anti-human $\mathrm{BK}_{\mathrm{Ca}} \beta 1$ (1:50) or $\gamma 1$ (1:50) subunit at $4{ }^{\circ} \mathrm{C}$ overnight. IgG was used as negative control. All antibody incubations were performed in $0.5 \%$ BSA/PBS. The sections were washed $3 \times 10$ min with PBS, and then incubated with Alexa ${ }^{568}$ mouse immunoglobulin (IgG, 1:1000) for $1 \mathrm{~h}$ at room temperature. After $3 \times 10$ min washing with PBS, the sections were blocked with $1 \% \mathrm{BSA} / \mathrm{PBS}$ for $30 \mathrm{~min}$ at room temperature. The sections were incubated with anti-human CD31 (1:200) at $4{ }^{\circ} \mathrm{C}$ overnight, washed, and then incubated with Alexa ${ }^{488}$ anti-mouse IgG (1:1000) for $1 \mathrm{~h}$ at room temperature. The sections were washed and then mounted with anti-fade mounting medium containing DAPI. Sections were examined under a confocal laser scanning microscope (Olympus SV3000) and images were acquired for quantifying levels of $\mathrm{BK}_{\mathrm{Ca}}$ subunits (mean red fluorescence intensity) in SMC and EC as previously described [12].

\subsection{RNA Extraction and Reverse Transcription Polymerase Chain Reaction (RT-PCR)}

Total RNAs were extracted from the main UA tissue $(\approx 100 \mathrm{mg})$ or cultured hUASMC $\left(\approx 2 \times 10^{5}\right.$ cells $)$ using Trizol reagent (Invitrogen, Carlsbad, CA, USA) and quantified by $\mathrm{OD}_{260 / 280}$. Complementary DNA was synthesized by reverse transcription with random primers and AMV Reverse Transcriptase 
(Promega, Madison, WI, USA) and then used for detecting mRNAs of $\mathrm{BK}_{\mathrm{Ca}}$ subunits by PCR with gene-specific primers as listed in Table 1. PCR was run as follows: $95^{\circ} \mathrm{C}$ for $5 \mathrm{~min}$, followed by 38 cycles of $95^{\circ} \mathrm{C}$ for $30 \mathrm{~s}, 62{ }^{\circ} \mathrm{C}$ for $30 \mathrm{~s}$, and $72{ }^{\circ} \mathrm{C}$ for $30 \mathrm{~s}$, and then $72{ }^{\circ} \mathrm{C}$ for $5 \mathrm{~min}$ and $4{ }^{\circ} \mathrm{C}$. The amplicons were confirmed by sequencing.

Table 1. Primers used for detecting human large conductance $\mathrm{Ca}^{2+}$-activated voltage-dependent potassium $\left(\mathrm{BK}_{\mathrm{Ca}}\right)$ channel subunits by RT-PCR.

\begin{tabular}{cccc}
\hline Subunits & Forward $\mathbf{( 5}^{\prime} \mathbf{- 3}^{\prime} \mathbf{)}$ & Reverse $\mathbf{( 5}^{\prime} \mathbf{- 3}^{\prime} \mathbf{)}$ & $\begin{array}{c}\text { Amplicon } \\
\mathbf{( b p )}\end{array}$ \\
\hline$\alpha$ & CTTCGTGGGTCTGTCCTTCC & TCTCTCGGTTGGCAGACTTG & 98 \\
$\beta 1$ & AAGTGCCACCTGATTGAGACC & CACAGGCATGGGTACTGGG & 80 \\
$\beta 2$ & GCACCGGATCGCTGTCATTA & TGGCAAAAAGACCTCCGGTA & 76 \\
$\beta 3$ & GAGAGGACCGAGCCGTGATG & CACCACCTAGCAGAGTCAGTGAAG & 513 \\
$\beta 4$ & GCGTTCTCATTGTGGTCC & TTCCAGTTGTGCCTGTTTC & 243 \\
$\gamma 1$ & CGCGTCAGAGGCCGAG & TGGCTAAAGGCGGCGTC & 90 \\
$\gamma 2$ & TCCTGGACTTCGCCATCTTC & TCAGCTCTGTGGGCTCCAC & 81 \\
$\gamma 3$ & TTGGGGCTCAACCCTAACAC & GAATTCCAGGGCCCCACTAC & 98 \\
$\gamma 4$ & TGGATCCAGGAGAACGCATC & TATCCTCCTGCTCTCCATGGG & 87 \\
\hline
\end{tabular}

\subsection{Western Blot}

UA and cultured hUASMC proteins were extracted using a lysis buffer as previously described [32]. Equal amounts of total protein extracts ( $20 \mu \mathrm{g} / \mathrm{lane}$ ) were separated on 10-15\% SDS-PAGE and transferred to polyvinylidene difluoride membrane. Proteins were determined by immunoblotting with antibodies against anti-human $\mathrm{BK}_{\mathrm{Ca}} \beta 1$ (1:100) or $\gamma 1$ (1:200) subunits in Tris-buffered saline (TBS) containing 5\% BSA as described previously [12]. $\beta$-actin was determined as a control for sample loading.

\subsection{Electrophysiology}

Electrophysiological experiments were performed as described previously [33,34]. Briefly, cultured primary hUASMC were used for whole-cell, inside-out, and outside-out recordings with an Axonpatch-200B connected to a Digidata 1322A using pClamp10 software (Molecular Devices, CA, USA). The patch pipettes were fabricated from borosilicate glass (Havard Apparatus) and had electrode resistances from 2-4 M $\Omega$ with an access resistance from 3-10 M $\Omega$. Cells with current leakage less than $100 \mathrm{pA}$ in the whole-cell mode were selected for analysis. Sampling frequencies for whole-cell current and single-channel recordings were $1 \mathrm{kHz}$ and $5 \mathrm{kHz}$, respectively. Data were filtered with a low-pass 4-pole Bessel filter set at $1 \mathrm{kHz}$, which results in a 10-90\% rise time of $350 \mu \mathrm{s}$. For whole-cell and outside-out single-channel recordings, the bath solution contained (mM) $144 \mathrm{NaCl}, 5 \mathrm{KCl}, 2 \mathrm{CaCl}_{2}$, $0.5 \mathrm{MgCl}_{2}, 10$ 2-[4-(2-hydroxyethyl)piperazin-1-yl]ethanesulfonic acid (HEPES), and 10 glucose, at $\mathrm{pH}$ 7.4 adjusted with $10 \mathrm{~N} \mathrm{NaOH}$. The recording pipette solution contained (mM) $140 \mathrm{KCl}, 1 \mathrm{MgCl}_{2}$, $5 \mathrm{Na}_{2} \mathrm{ATP}, 5 \mathrm{EGTA}$, and $2.5 \mathrm{CaCl}_{2}$, at $\mathrm{pH}$ 7.2. The final free $\mathrm{Ca}^{2+}$ concentration was calculated by the Webmaxc extended calculator (http://www.stanford.edu/ cpatton/webmaxcE.htm) and estimated to be $10 \mu \mathrm{M}$ in the control pipette solution, which was adjusted for indicated free $\mathrm{Ca}^{2+}$ concentration in the text by changing $\mathrm{CaCl}_{2}$ concentration or by adding EGTA.

$\mathrm{BK}_{\mathrm{Ca}}$ channels keep open with intracellular free $\mathrm{Ca}^{2+}$ higher than $50 \mu \mathrm{M}$ [35], making it hard to qualify the channel activity with a continuous high free $\mathrm{Ca}^{2+}$ level. Thus, we performed all the tests with intracellular free $\mathrm{Ca}^{2+}$ no higher than $10 \mu \mathrm{M}$. $\mathrm{Ca}^{2+}$-free recordings were performed with the same bath solution containing 5 mM EGTA. Channel blockers were added into the bath solutions unless stated otherwise. For inside-outside single-channel recordings, the pipette and the bathe solutions are the same as the pipette solutions of whole-cell recordings as described above. Test solutions were applied via a gravity-driven system controlled by VCS-66MCS (Warner Instrument, Hemden, CT, USA). For rapid solution exchange $(\approx 300-500 \mathrm{~ms})$, we held membrane patches in a stream of the experimental solution from a second pipette. Single-channel current amplitudes were calculated by fitting amplitude 
histograms to a Gaussian distribution. Channel open probability was expressed as $P_{\text {open }}=\mathrm{NPo} / \mathrm{n}$, where NPo $=[($ to $) /($ to + tc $)]$. $P_{\text {open }}=$ open probability for one channel; to $=$ sum of open times; tc $=$ sum of closed times; $\mathrm{N}=$ actual number of channels in the patch; and $\mathrm{n}=$ maximum number of individual channels observed in the patch. Experiments were repeated at least 3 times and data were calculated as the mean \pm SEM (standard error of the mean). The linear regression is shown in the single channel current-voltage (I-V) curve. $P_{\text {open }}$ was fit with Gaussian function. Single-channel conductance (g, pico Siemens, pS) was calculated using I/U; I = single-channel current (pA), $U$ = membrane potential (mV).

The whole-cell patch-clamp technique was used to record $\mathrm{K}_{\mathrm{ATP}}$ channel currents as previously described [18]. The bath solution for recording whole-cell $\mathrm{K}_{\mathrm{ATP}}$ current contained (mM) $140 \mathrm{NaCl}$, $5.4 \mathrm{KCl}, 1.2 \mathrm{MgCl}_{2}, 10 \mathrm{HEPES}, 1 \mathrm{EGTA}$, and 10 glucose, with $\mathrm{pH}$ adjusted to 7.4 with $\mathrm{NaOH}$. The pipette solution contained $(\mathrm{mM}) 140 \mathrm{KCl}, 1 \mathrm{MgCl}_{2}, 10 \mathrm{EGTA}, 10 \mathrm{HEPES}, 5$ glucose, $0.3 \mathrm{Na}_{2} \mathrm{ATP}$, and $0.5 \mathrm{MgGDP}$, with $\mathrm{pH}$ adjusted to 7.2 with $\mathrm{KOH}$. Cells were superfused continuously with the bath solution at a rate of approximately $2 \mathrm{~mL} / \mathrm{min}$. Solution change in the recording chamber was accomplished within $30 \mathrm{~s}$.

All patch clamp recordings were carried out at room temperature $\left(20-22{ }^{\circ} \mathrm{C}\right)$. NaHS was used as a source of $\mathrm{H}_{2} \mathrm{~S}$; working solutions were prepared immediately before use as $\mathrm{H}_{2} \mathrm{~S}$ gas evaporates $10-15 \%$ from the solution within $30 \mathrm{~min}$ at $37^{\circ} \mathrm{C}$ [36]. Stock solution of nifedipine was dissolved in DMSO; the final DMSO concentration did not exceed $0.05 \%$, which did not change the currents in control experiments.

\subsection{Organ Bath Studies}

Freshly prepared UA rings (2-5 mm in length) were placed in ice-cold Krebs-Ringer bicarbonate (KRB) bath solution containing (mM) $118.5 \mathrm{NaCl}, 4.75 \mathrm{KCl}, 1.2 \mathrm{MgSO}_{4}, 1.2 \mathrm{KH}_{2} \mathrm{PO}_{4}, 25 \mathrm{NaHCO}_{3}$, $2.5 \mathrm{CaCl}_{2}$, and 5.5 glucose, with $\mathrm{pH} 7.4$ adjusted with $\mathrm{HCl}$. The UA rings were mounted onto a tension transducer $(\mathrm{JZJ} 01 \mathrm{H})$ under a stable resting tension in organ bath chambers containing $5 \mathrm{~mL}$ of KRB solution at $37{ }^{\circ} \mathrm{C}$, gassed with $95 \% \mathrm{O}_{2}$ and $5 \% \mathrm{CO}_{2}$. The rings were allowed to equilibrate for at least $30 \mathrm{~min}$, with chamber solution changed every $15 \mathrm{~min}$. Endothelium integrity was determined by response to $10 \mu \mathrm{M}$ acetylcholine as previously described [12]. Only endothelium-intact rings were used, which were preload with a tension at $1.5 \mathrm{~g}$ after equilibration; contraction was recorded when the tension was stable for at least $15 \mathrm{~min}$. Rings were pre-contracted with $10 \mu \mathrm{M}$ phenylephrine. Rings rapidly responding to phenylephrine in $5 \mathrm{~min}$ with more than $2 \mathrm{mN}$ contraction were selected for recording the dose-response relaxation curves of $\mathrm{NaHS}$ in the presence or absence of the selective $\mathrm{BK}_{\mathrm{Ca}}$ channel blockers. Each drug was allowed at least $5 \mathrm{~min}$ to respond. Changes in the isometric tension were recorded and analyzed with a Multiple Channel Physiology Signal Recording System (RM-6240EC, Chengdu Instrument Factory, Chengdu, China).

\subsection{Statistics}

Results are expressed as means \pm standard error. Significant levels were determined by using the paired Student's $t$-test or one-way ANOVA followed by Bonferroni test for multiple comparisons, whichever appropriate, using GraphPad Prism 8. Significant difference was accepted at $p<0.05$.

\section{Results}

\subsection{Expression of $B K_{C a}$ Channels in UA In Vitro and Primary UASMC In Vitro}

$\mathrm{BK}_{\mathrm{Ca}}$ channels are tetramer formed by the pore-forming $\alpha$ subunits, along with the regulatory $\beta 1-4$ and $\gamma 1-4$ subunits [22,23]. By using RT-PCR and sequencing conformation, we detected $\alpha, \beta 1$, $\beta 3, \beta 4$, and $\gamma 1-3$, but not $\beta 2$ and $\gamma 4$, mRNAs in pregnant human UA and cultured primary hUASMC (Figure 1A). Since $\beta 1, \gamma 1$, and $\gamma 3$ subunits are the most important ones for mediating UA adaptation to pregnancy $[27,31,37]$, we further examined their proteins in human uterine arteries and cultured hUASMC. We tested two commercially available antibodies against $\gamma 1$ and $\gamma 3$ subunits to detect their protein levels by Western blot and immunofluorescence microscopy. The $\gamma 1$ subunit was only 
detectable by Western blot with one antibody (PA5-38058) but not by immunofluorescence microscopy, whereas $\gamma 3$ subunit was detectable by immunofluorescence microscopy with the Abcam antibody (ab121412) but not by Western blot with all other commercial antibodies. Immunoblotting detected $\beta 1$ and $\gamma 1$ proteins in both UA and cultured hUASMC and they did not change in three passages (Figure 1B). Immunofluorescence microscopy analysis revealed that both VSM and EC expressed $\beta 1$ and $\gamma 3$ proteins; however, levels of both $\beta 1$ and $\gamma 3$ proteins in SM cells were significantly greater than that in the $\mathrm{CD} 1^{+} \mathrm{EC}$. In addition, histological analysis showed that both $\beta 1$ and $\gamma 3$ proteins are not expressed in all ECs as $\beta 1$ or $\gamma 3$ proteins were only found in some regions of the $\mathrm{CD}^{+} 1^{+} \mathrm{EC}$ linings (Figure 1C).
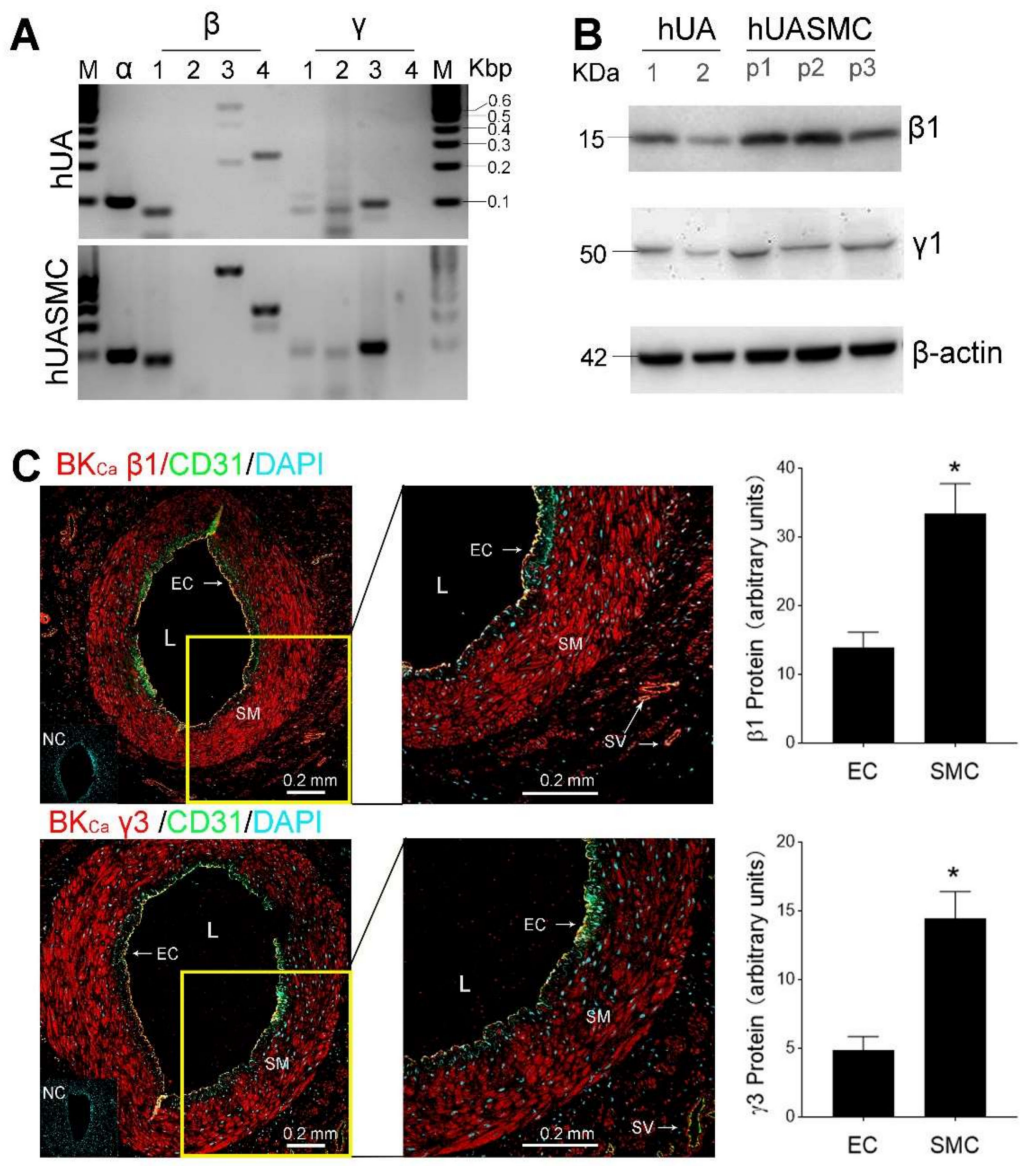

Figure 1. $\mathrm{BK}_{\mathrm{Ca}}$ channel expression in human uterine artery. (A) Expression of mRNAs of $\mathrm{BK}_{\mathrm{Ca}}$ subunits in human uterine artery (hUA, upper panel) and cultured primary hUA smooth muscle cells (hUASMC, lower panel). Steady-state mRNAs of $\alpha, \beta 1-4$, and $\gamma 1-4$ subunits were detected by RT-PCR. The amplicons were sequencing confirmed. M, 100 bp DNA ladder. (B) $\beta 1$ and $\gamma 1$ proteins detected by immunoblotting in hUA from two women and primary hUASMC in three passages (P). (C) Localization of $\beta 1$ and $\gamma 3$ proteins by immunofluorescence microscopy. SMC; smooth muscle cells; EC; endothelial cells; L; lumen; NC: negative control; SV; small vessels. Graph summarized levels of EC and SMC $\beta 1$ and $\gamma 3$ proteins $(n=3) .{ }^{*} p<0.05$.

\subsection{Functional $B K_{C a}$ Channels in Primary hUASMC In Vitro}

To determine if $\mathrm{BK}_{\mathrm{Ca}}$ channels were functional in cultured hUASMC, we introduced whole-cell and single-channel patch clamp with the selective $\mathrm{BK}_{\mathrm{Ca}}$ channel blockers: iberiotoxin (IBTX, $100 \mathrm{nM}$ ) or low concentration of TEA $(1 \mathrm{mM})$. Ion currents were elicited in response to a series of voltage pulses from $-60 \mathrm{mV}$ holding potential to $+80 \mathrm{mV}$ in steps of $10 \mathrm{mV}$. Both IBTX and TEA blocked the outward current significantly compared with the baseline holding membrane potential from $+40 \mathrm{mV}$ 
to $+80 \mathrm{mV}(p<0.05$, Figure $2 \mathrm{~A}-\mathrm{C})$. In the inside-out patch, cultured hUASMC BK $\mathrm{Ca}$ channels showed a single-channel conductance of $201 \pm 19.08 \mathrm{pS}(n=8)$ in a symmetrical high $\mathrm{K}^{+}$solution $(140 \mathrm{mM})$ on both sides of the cell membrane, which was consistent with reported values [38] (Figure 2D,E). In outside-out/inside-out single-channel recording with $100 \mathrm{nM}$ free $\mathrm{Ca}^{2+}$ in the pipette solution at +40 $\mathrm{mV}$ holding membrane potential, the observed single-channel activities were blocked by IBTX or TEA, confirming the observed $200 \mathrm{pS}$ channels to be $\mathrm{BK}_{\mathrm{Ca}}$ channels (Figure $2 \mathrm{~F}$ ). Open probability $\left(P_{\text {open }}\right)$ of the channels was decreased from $0.04 \pm 0.009(n=10)$ to $0.0019 \pm 0.00046(n=5, p<0.05)$ by IBTX, and to $0.0026 \pm 0.0011(n=5, p<0.05)$ by TEA. These results indicate the presence of IBTX- and TEA-sensitive functional $\mathrm{BK}_{\mathrm{Ca}}$ channels in hUASMC in vitro.
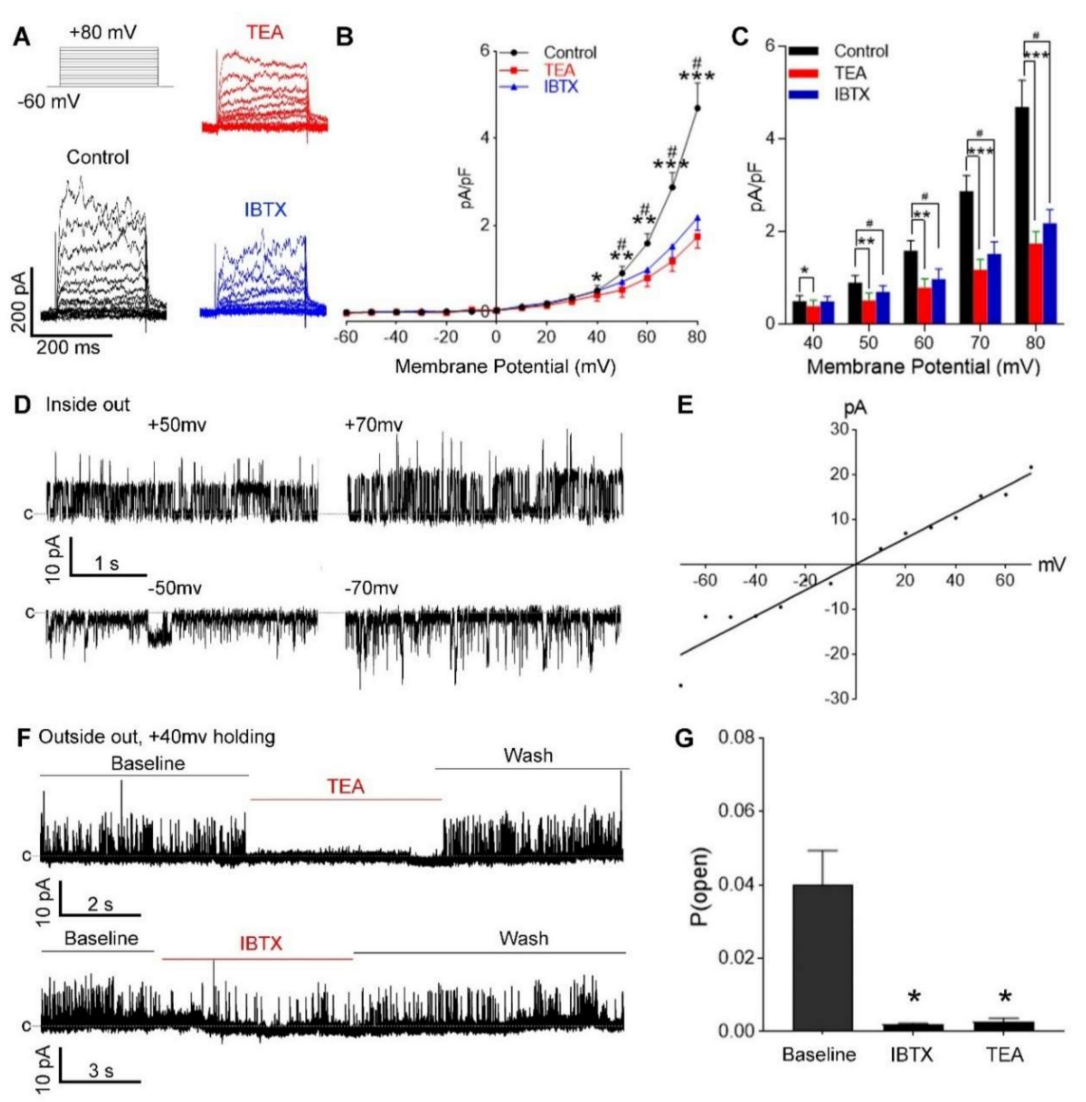

Figure 2. Functional $\mathrm{BK}_{\mathrm{Ca}}$ channels in primary hUASMC in vitro. (A) The top-left figure shows voltage-triggered protocol of the whole-cell patches, in which cells were held at $-60 \mathrm{mV}$ followed by a $10-\mathrm{mV}$ voltage increment until $+80 \mathrm{mV}$. Representative voltage-dependent current sweeps of cultured hUASMC in control (black), tetraethylammonium (TEA) (1 mM, red), and iberiotoxin (IBTX) (100 nM, blue) groups. (B,C) Current density was used to quantify channel activity, illustrated as current/capacitance $(\mathrm{pA} / \mathrm{pF})$. Both TEA (red) and IBTX (blue) inhibited ion currents significantly from holding potential of $+40 \mathrm{mV}$ to $+80 \mathrm{mV}$. \# $p<0.05,{ }^{*} p<0.05$; ${ }^{* *} p<0.01 ;{ }^{* * *} p<0.001$; IBTX or TEA vs. control. (D,E) Inside-out patch of cultured hUASMC with symmetrical $140 \mathrm{mM} \mathrm{K} \mathrm{K}^{+}$showed outward currents with holding potential of +50 and $+70 \mathrm{mV}$ (upper panel in (D)), and inward currents at -50 and $-70 \mathrm{mV}$ (lower panel in (D)), in which a conductance of $\approx 250 \mathrm{pS}$ in the representative trace indicates the presence of big conductance $\mathrm{K}^{+}$channels. (F) The big conductance $\mathrm{K}^{+}$channels were sensitive to TEA (upper panel) and IBTX (lower panel) in outside-out patch with $100 \mathrm{nM}$ free $\mathrm{Ca}^{2+}$ in pipette solution. $(\mathrm{G})$ Open probability $\left(P_{\text {open }}\right)$ was used to quantify $\mathrm{BK}_{\mathrm{Ca}}$ activity. ${ }^{*} p<0.05$ vs. baseline. $\mathrm{c}$ indicates the close state of channels.

To determine if $\mathrm{BK}_{\mathrm{Ca}}$ channels were functional in cultured hUASMC, we introduced whole-cell and single-channel patch clamps with the selective $\mathrm{BK}_{\mathrm{Ca}}$ channel blockers, IBTX (100 nM) and low 
concentration of TEA (1 mM), separately. Ion currents were elicited in response to a series of voltage pulses from $-60 \mathrm{mV}$ holding potential to $+80 \mathrm{mV}$ in steps of $10 \mathrm{mV}$. Both IBTX and TEA significantly blocked the outward current in comparison with the baseline holding membrane potential from $+40 \mathrm{mV}$ to $+80 \mathrm{mV}(p<0.05$, Figure $2 \mathrm{~A}-\mathrm{C})$. In the inside-out patch, cultured hUASMC BK $\mathrm{Ca}$ channels showed a single-channel conductance of $201 \pm 19.08 \mathrm{pS}(n=8)$ in a symmetrical high $\mathrm{K}^{+}$solution $(140 \mathrm{mM})$ on both sides of the cell membrane (Figure 2D,E). With $100 \mathrm{nM}$ free $\mathrm{Ca}^{2+}$ in the pipette solution at $+40 \mathrm{mV}$ holding membrane potential, the single-channel $\mathrm{BK}_{\mathrm{Ca}}$ currents were blocked by IBTX or TEA (Figure $2 \mathrm{~F}) . P_{\text {open }}$ of $\mathrm{BK}_{\mathrm{Ca}}$ decreased significantly from $0.04 \pm 0.009(n=10)$ to $0.0019 \pm 0.00046(n=5$, $p<0.05)$ by IBTX, and to $0.0026 \pm 0.0011(n=5, p<0.05)$ by TEA, indicating the presence of IBTX- and TEA-sensitive functional $\mathrm{BK}_{\mathrm{Ca}}$ channels in primary hUASMC in vitro.

\section{3. $\mathrm{H}_{2} \mathrm{~S}$ Increased $\mathrm{Ca}^{2+}$-Activated and Voltage-Dependent $\mathrm{K}^{+}$Currents in hUASMC}

When sodium hydrosulfide (NaHS) was applied to the extracellular solution, it rapidly dissociated into $\mathrm{Na}^{+}$and $\mathrm{HS}^{-}$, and $\mathrm{HS}^{-}$associated with $\mathrm{H}^{+}$to produce $\mathrm{H}_{2} \mathrm{~S}$. However, only the $\mathrm{H}_{2} \mathrm{~S}$ molecule, but not $\mathrm{HS}^{-}$, is able to pass the plasma membrane, as $\mathrm{H}_{2} \mathrm{~S}$ possess approximately fivefold greater lipophilic solubility than water [39]. Addition of NaHS (100 $\mathrm{MM})$ caused a significant and reversible increase of membrane outward currents, and current voltage relationships were obtained within 1-3 min after NaHS incubation. NaHS on $\mathrm{BK}_{\mathrm{Ca}}$ activity was assessed with whole-cell and single-channel recordings. NaHS significantly augmented the whole-cell outward current from $60 \mathrm{mv}$ membrane potential ( $p<0.05$, Figure 3A-C), which was sensitive to $1 \mathrm{mM}$ TEA $(p<0.05$, Figure 3A-C), indicating that the augmented outward currents were $\mathrm{BK}_{\mathrm{Ca}}$-mediated. In single-channel recordings, $\mathrm{NaHS}$ increased $P_{\text {open }}$ from baseline $(0.1258 \pm 0.01)$ to $0.3107 \pm 0.02$, and standard bath solution reversed the NaHS-induced $P_{\text {open }}$ to $0.1533 \pm 0.01$; most of the outward currents were sensitive to 1 mM TEA $(p<0.05$, Figure $3 \mathrm{~A}-\mathrm{C})$. With $10 \mu \mathrm{M}$ free $\mathrm{Ca}^{2+}$ in the pipette solution at $+40 \mathrm{mV}$ holding membrane potential, NaHS increased $P_{\text {open }}$ of $\mathrm{BK}_{\mathrm{Ca}}$ from $0.468 \pm 0.04226$ to $0.7742 \pm 0.02664(p<0.01)$. The $\mathrm{H}_{2} \mathrm{~S}$-induced $P_{\text {open }}$ of $\mathrm{BK}_{\mathrm{Ca}}$ was also observed at lower holding potentials from $-10 \mathrm{mV}$ to $+20 \mathrm{mV}(n=6, p<0.05 \mathrm{vs}$. baseline, Figure $3 \mathrm{~F})$. NaHS stimulated $\mathrm{BK}_{\mathrm{Ca}}$ activity in a U-shaped concentration-dependent manner; $\mathrm{NaSH}$ at 100 and $500 \mu \mathrm{M}$ significantly increased $P_{\text {open }}$ of $\mathrm{BK}_{\mathrm{Ca}}$ channels by $166.6 \pm 29 \%$ and $198.1 \pm 35 \%$ $(n=10)$, respectively. Low $(10 \mu \mathrm{M})$ and high $(1 \mathrm{mM})$ concentrations of NaHS also increased $P_{\text {open }}$ by $134.9 \pm 24 \%$ and $160.2 \pm 62 \%(n=10)$, but these responses did not differ statistically from the controls (Figure 3G).

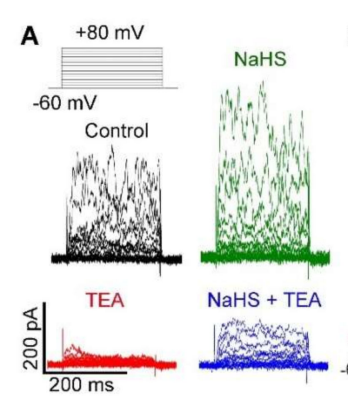

B

C
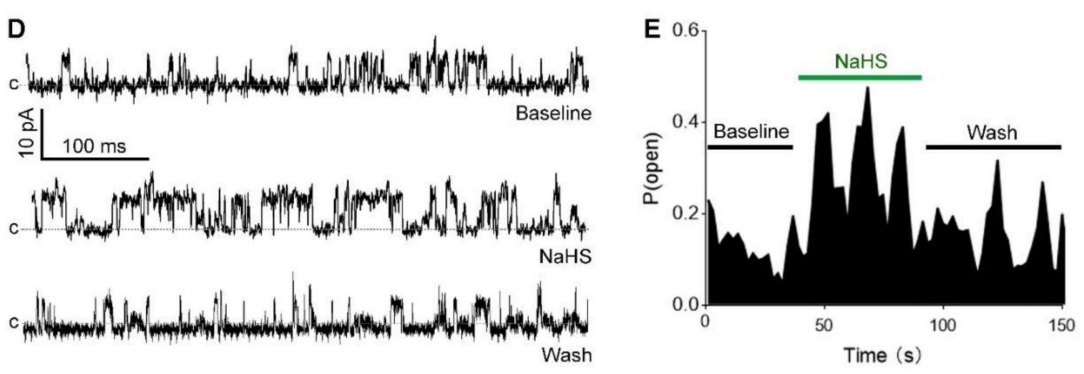

Figure 3. Cont. 

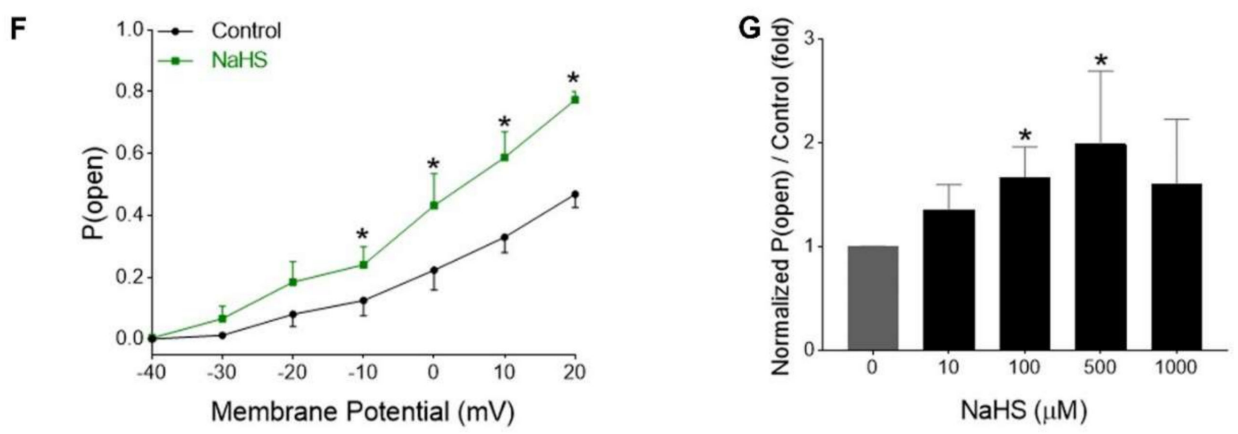

Figure 3. $\mathrm{H}_{2} \mathrm{~S}$ activation of $\mathrm{BK}_{\mathrm{Ca}}$ in hUASMC. (A) Representative sweeps of voltage-dependent currents in control (black), TEA (red), $\mathrm{H}_{2} \mathrm{~S}$ doner NaHS (green), and NaHS + TEA (blue) groups. NaHS increased whole-cell currents (green), and TEA blocked NaHS-induced currents (blue). (B,C) Current densities in control $(n=10)$, NaHS $(n=10)$, TEA $(n=5)$, and NaHS + TEA $(n=5)$ groups. ${ }^{*} p<0.05$, NaHS vs. control; \#\#\# $p<0.001$, TEA vs. control. In addition to TEA-sensitive channels, NaHS also activated TEA-insensitive channels. \# $p<0.05$ TEA vs. NaHS + TEA. (D,E) Representative outside-out single-channel currents of $\mathrm{BK}_{\mathrm{Ca}}$ in baseline, $\mathrm{NaHS}$, and washout with standard bath solutions at holding potential of $+40 \mathrm{mV}$ and with $10 \mu \mathrm{M}$ free $\mathrm{Ca}^{2+}$ in the pipette solution. (F) $P_{\text {open }}$ of $\mathrm{BK}_{\mathrm{Ca}}$ was also augmented in lower membrane potentials of $-10 \mathrm{mV}$ to $+20 \mathrm{mV}(n=6$ in control and $n=4$ in NaHS groups). ${ }^{*} p<0.05$, vs. control. (G) Dose-response of $\mathrm{NaHS}$ on $\mathrm{BK}_{\mathrm{Ca}}$ channel activity. $n=10$ /group. $c$ : indicates the close state of channels.

\section{4. $\mathrm{H}_{2} \mathrm{~S}$ Activation of hUASMC BKCa Was Independent of Extracellular $\mathrm{Ca}^{2+}$}

Voltage and cytosolic $\mathrm{Ca}^{2+}$ are the two major regulatory components physiologically for $\mathrm{BK}_{\mathrm{Ca}}$ channels $[40,41]$. To analyze whether $\mathrm{H}_{2} \mathrm{~S}$-induced activity in hUASMC BK $\mathrm{Ca}$ depends on voltage and cytosolic $\mathrm{Ca}^{2+}$, we determined the effects of extracellular and intracellular $\mathrm{Ca}^{2+}$ on the NaHS $(100 \mu \mathrm{M})$-induced $P_{\text {open }}$ of $\mathrm{BK}_{\mathrm{Ca}}$, holding at different membrane potentials from $-60 \mathrm{mV}$ to $+80 \mathrm{mV}$. The representative traces showed $P_{\text {open }}$ in response to voltage ramp in control and NaHS groups (Figure $4 \mathrm{~A}$ ). Following NaHS treatment, $P_{\text {open }}$ of $\mathrm{BK}_{\mathrm{Ca}}$ increased by $137.8 \pm 24 \%$ at $10 \mathrm{mV}, 181.4 \pm 17 \%$ $(p<0.05)$ at $+20 \mathrm{mV}$, and $237 \pm 57 \%(p<0.05)$ at $+40 \mathrm{mV}$. The increases in the NaHS-induced $P_{\text {open }}$ of $\mathrm{BK}_{\mathrm{Ca}}$ were less effective when holding potentials were higher than $+50 \mathrm{mV}$, by $161.5 \pm 22 \%, 146.7 \pm 24 \%$, $139.4 \pm 14 \%$, at $+60 \mathrm{mV},+70 \mathrm{mV}$, and $+80 \mathrm{mV}$, respectively (Figure $4 \mathrm{~B}$ ). When the holding pipette solution $\mathrm{Ca}^{2+}$ concentrations were $0,0.1$, and $10 \mu \mathrm{M}$, the NaHS-induced $P_{\text {open }}$ of $\mathrm{BK}_{\mathrm{Ca}}$ increased by $193 \pm 39 \%(p<0.05, n=4), 172 \pm 26 \%(p<0.05, n=5)$, and $150.5 \pm 14 \%(n=6, p<0.05)$, respectively (Figure $4 \mathrm{C}$ ). NaHS also induced comparable significantly increased $P_{\text {open }}$ of $\mathrm{BK}_{\mathrm{Ca}}$ from holding potential of $+10 \mathrm{mV}$ to $+80 \mathrm{mV}$ when thylene glycol-bis( $\beta$-aminoethyl ether)-N,N, $\mathrm{N}^{\prime}, \mathrm{N}^{\prime}$-tetraacetic acid (EGTA, $5 \mathrm{mM}$ ) was added in the bath solution, which should eliminate free $\mathrm{Ca}^{2+}$ (Figure 4D). When a $\mathrm{Ca}^{2+}$ channel blocker nifedipine $(5 \mu \mathrm{M})$ was applied, it also did not affect the NaHS-induced $P_{\text {open }}$ of $\mathrm{BK}_{\mathrm{Ca}}($ Figure $4 \mathrm{E})$. 

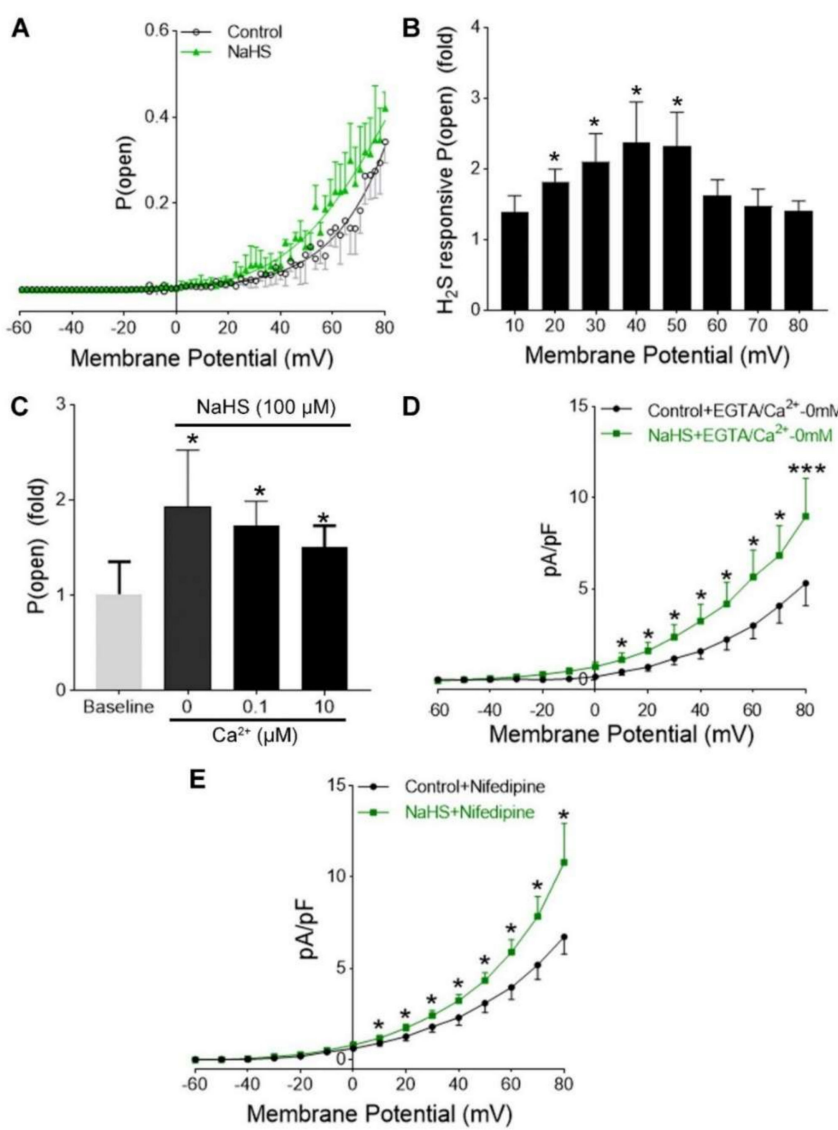

Figure 4. Properties of $\mathrm{H}_{2} \mathrm{~S}$-responsive $\mathrm{BK}_{\mathrm{Ca}}$ in hUASMC in vitro. (A) Open probability $\left(P_{\text {open }}\right)$ of $\mathrm{BK}_{\mathrm{Ca}}$ recorded with membrane potential of $-60 \mathrm{mV}$ to $+80 \mathrm{mV}$ in outside-out single-channel mode. (B) $P_{\text {open }}$ with different membrane potentials with and without $100 \mu \mathrm{M} \mathrm{NaHS}$. NaHS increased $P_{\text {open }}$ with membrane potential of +20 to $+50 \mathrm{mV} .{ }^{*} p<0.05, \mathrm{NaSH}$ vs. control at each membrane potential $(n=8)$. (C) $\mathrm{Ca}^{2+}$ concentrations $(0,0.1$, and $10 \mu \mathrm{M})$ in pipette solution on $P_{\text {open }}$ of $\mathrm{BK}_{\mathrm{Ca}}$ channels in response to NaHS at $-60 \mathrm{mv}$ membrane potential. ${ }^{*} p<0.05$ vs. baseline. (D) Bath solution with $5 \mathrm{mM}$ EGTA on current density in response to NaHS at $-60 \mathrm{mv}$ membrane potential. NaHS $(n=11)$ increased current density in free $\mathrm{Ca}^{2+}$ bath solution. ${ }^{*} p<0.05,{ }^{* * *} p<0.001$ vs. control; $n=11$ /group. (E) Effects of nifedipine $(5 \mu \mathrm{M})$ in bath solution on NaHS $(100 \mu \mathrm{M})$-induced current density. ${ }^{*} p<0.05$ vs. control; $n=6 /$ group.

\section{5. $\mathrm{H}_{2} \mathrm{~S}$-Induced $\mathrm{BK} \mathrm{Ca}_{\mathrm{Ca}}$ Activation Is Redox-Sensitive}

The activity of $\mathrm{BK}_{\mathrm{Ca}}$ channels depends on the redox state of the sulfhydryl groups in the channel proteins [42-44], and oxidation reduces $\mathrm{BK}_{\mathrm{Ca}}$ activity [45,46]. To study if the NaHS-induced $\mathrm{BK}_{\mathrm{Ca}}$ activation is redox-dependent, we determined the effects of a reducing agent dithiothreitol (DTT, $1 \mathrm{mM}$ ) added into the bath solution on the NaHS-induced $P_{\text {open }}$ of $\mathrm{BK}_{\mathrm{Ca}}$. Treatment with NaHS increased $P_{\text {open }}$ of $\mathrm{BK}_{\mathrm{Ca}}$ from baseline $0.036 \pm 0.011$ to $0.119 \pm 0.032(p<0.05)$; co-incubation with DTT decreased the NaSH-induced $P_{\text {open }}$ of $\mathrm{BK}_{\mathrm{Ca}}$ to $0.072 \pm 0.034(p<0.05)$ (Figure $\left.5 \mathrm{~A}, \mathrm{~B}\right)$. Co-incubation with DDT blocked NaHS-induced $\mathrm{BK}_{\mathrm{Ca}}$ activation; however, this effect was rapidly diminished and then all channel activities were blocked (Figure 5C). DTT alone did not alter $\mathrm{BK}_{\mathrm{Ca}}$ channel $\mathrm{P}_{\text {open }}$ (Figure 5B,C). 
A
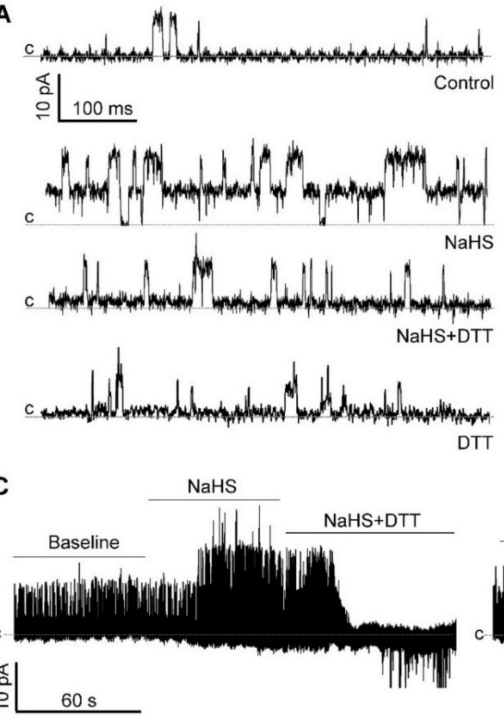

B
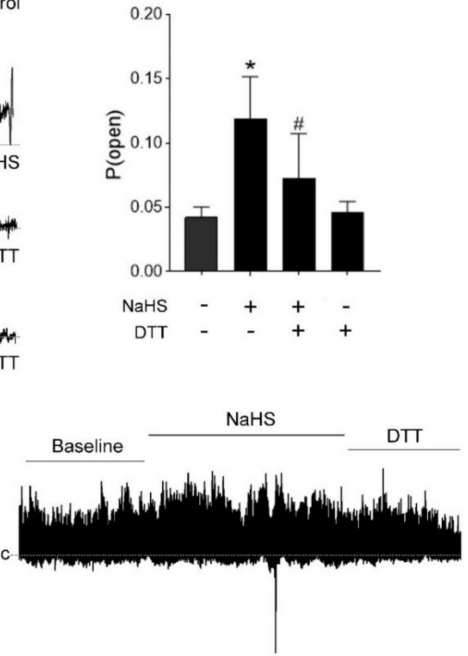

Figure 5. The $\mathrm{BK}_{\mathrm{Ca}}$ channel opening activity of $\mathrm{H}_{2} \mathrm{~S}$ was redox-sensitive. (A) Original outside-out single-channel currents with dithiothreitol (DTT, $1 \mathrm{mM}$ ) in the pipette solution before and during NaHS $(100 \mu \mathrm{M})$ application. Holding potentials were $+60 \mathrm{mV}$ with $0.1 \mu \mathrm{M}$ free $\mathrm{Ca}^{2+}$ in the pipette solution. (B) Open probability $\left(P_{\text {open }}\right.$ of $\mathrm{BK}_{\mathrm{Ca}}$ was significantly increased from $0.036 \pm 0.011(n=7)$ in the control group to $0.119 \pm 0.032(n=7)$ by $100 \mu \mathrm{M}$ NaHS; the addition of DTT decreased the $\mathrm{H}_{2} \mathrm{~S}$-induced $P_{\text {open }}$ to $0.072 \pm 0.034(n=6) .{ }^{*} p<0.05$ compared with control group; $\# p<0.05$ compared with NaHS group. $P_{\text {open }}$ was $0.046 \pm 0.008(n=4)$ in the presence of DTT alone. (C) DTT on NaHS $(100 \mu \mathrm{M})$ stimulated outside-out single-channel currents. Co-incubation with DTT $(1 \mathrm{mM})$ blocked the outward currents (left), while DTT alone did not alter baseline outward current (right). Currents represent similar experiments from different cells. $c$ : indicates the close state of channels.

\section{6. $\mathrm{H}_{2} \mathrm{~S}$ Relaxed Human $U A$ via $B K_{C a}$ Channel}

Incubation with increasing concentrations $(1,10,100,500 \mu \mathrm{M}) \mathrm{NaHS}$ stimulated dose-dependent relaxation of freshly prepared human UA rings that were pre-constricted with $10 \mu \mathrm{M}$ phenylephrine (Figure 6A). Pretreatment with the selective $\mathrm{BK}_{\mathrm{Ca}}$ channel inhibitor IBTX (100 nM) blocked the NaHS-induced UA relaxation (Figure 6B).
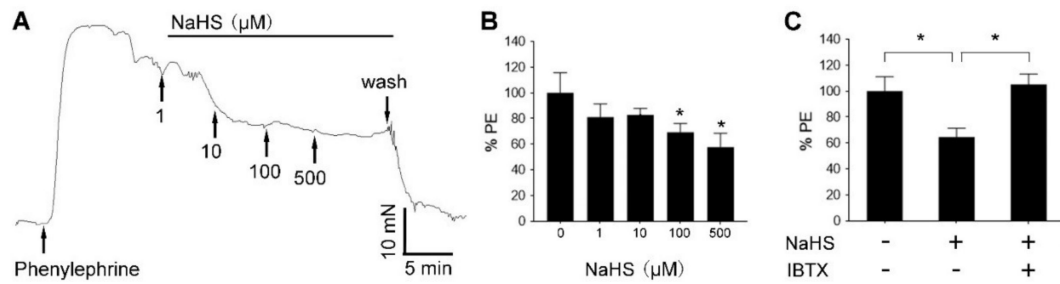

Figure 6. $\mathrm{BK}_{\mathrm{Ca}}$ in $\mathrm{H}_{2} \mathrm{~S}$-induced relaxation of human uterine artery in vitro. (A) Freshly prepared human main uterine artery (UA) rings were preconstricted with phenylephrine $(\mathrm{PE}, 10 \mu \mathrm{M})$ in organ bath to achieve steady contraction for at least $5 \mathrm{~min}$. Increasing concentrations $(1,10,100$, and $500 \mu \mathrm{M})$ of NaHS was then applied sequentially to relax the preconstricted UA ring. A representative dose-response curve of $\mathrm{H}_{2} \mathrm{~S}$-induced UA relaxation was shown to represent similar results of three UA ring preparations from three patients. (B) Bar graph summarizing the effects of NaHS on human UA (hUA) relaxation. $\mathrm{NaHS}$ at 100 and $500 \mu \mathrm{M}$ decreased the artery tension to $69.3 \pm 6.6 \%$ and $57.6 \pm 10.8 \%$ of the maximum contraction of PE. * $p<0.05$ compared with NaHS at 0 . (C) NaHS $(100 \mu \mathrm{M})$ decreased artery tension to $64.6 \pm 6.7 \%$ of the maxi contraction induced by PE, and the NaHS-induced UA relaxation was reversed by co-incubation with the $\mathrm{BK}_{\mathrm{Ca}}$ channel blocker iberiotoxin (IBTX, $100 \mathrm{nM}$ ). ${ }^{*} p<0.05$. 


\section{7. $\mathrm{H}_{2} \mathrm{~S}$ Did Not Activate $\mathrm{K}_{\text {ATP }}$ Channels in hUASMC}

Since $\mathrm{K}_{\text {ATP }}$ channels are direct effectors of $\mathrm{H}_{2} \mathrm{~S}[36,47,48]$, we determined whether $\mathrm{H}_{2} \mathrm{~S}$ activates $\mathrm{K}_{\text {ATP }}$ channels in hUASMC. Treatment with NaHS $(300 \mu \mathrm{M})$ [18] did not alter baseline inward currents stimulated by $140 \mathrm{mM} \mathrm{K}^{+}$, indicative of $\mathrm{K}_{\mathrm{ATP}}$ channel activity (Figure 7A); however, co-incubation with the $\mathrm{K}_{\text {ATP }}$ channel blocker glibenclamide $(10 \mu \mathrm{M})$ inhibited $\mathrm{K}_{\text {ATP }}$ channel activity (Figure 7A,B).
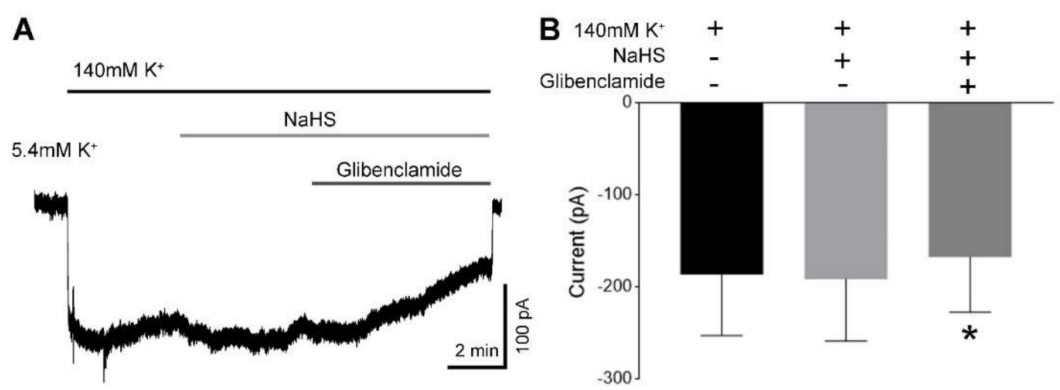

Figure 7. $\mathrm{H}_{2} \mathrm{~S}$ on $\mathrm{K}_{\mathrm{ATP}}$ channel activity in hUASMC. (A) $\mathrm{K}_{\text {ATP }}$ channel currents were recorded with symmetrical $140 \mathrm{mM} \mathrm{K}^{+}$with $0.3 \mathrm{mM}$ ATP in the pipette solution and the membrane potential was held at $-60 \mathrm{mV}$. NaHS $(300 \mu \mathrm{M})$ did not affect the inward $\mathrm{K}^{+}$currents. (B) Co-incubation with the $\mathrm{K}_{\mathrm{ATP}}$ channel blocker glibenclamide $(10 \mu \mathrm{M})$ inhibited the inward currents significantly, as shown in (B). ${ }^{*} p<0.05$ vs. baseline current induced by $140 \mathrm{mM} \mathrm{K}^{+}$without NaHS and glibenclamide. $n=3$ /group.

\section{Discussion}

Consistent with the well-documented vasodilatory effect of $\mathrm{H}_{2} \mathrm{~S}$ in many systemic arteries $[15,36,49,50]$, we were the first to report that $\mathrm{H}_{2} \mathrm{~S}$ dilates pressurized $\mathrm{UA}$ in a pregnancyand vascular bed-dependent manner in rats [12]. The current study demonstrates for the first time that $\mathrm{H}_{2} \mathrm{~S}$ activates $\mathrm{BK}_{\mathrm{Ca}}$ channels in hUASMC, as well as the fact that incubation of the specific $\mathrm{BK}_{\mathrm{Ca}}$ channel blocker IBTX completely blocks $\mathrm{H}_{2} \mathrm{~S}$-induced relaxation of pre-constricted human UA rings in vitro. These findings provide direct evidence for a role of smooth muscle $\mathrm{BK}_{\mathrm{Ca}}$ channels in mediating the vasodilatory effects of $\mathrm{H}_{2} \mathrm{~S}$ in the $\mathrm{UA}$, further supporting the notion that $\mathrm{H}_{2} \mathrm{~S}$ is a novel UA vasodilator.

Endogenous $\mathrm{H}_{2} \mathrm{~S}$ is a gaseous signaling molecule that is mainly synthesized by CBS and CSE in various human tissues, while other enzymes such as 3-mercaptopyruvate sulfurtransferase (3MST) in combination with cysteine aminotransferase (CAT) may also play a role [51]. Our recent studies have consistently shown that $\mathrm{H}_{2} \mathrm{~S}$ production is upregulated in the UA via selectively upregulating EC and SM CBS expression, without altering the expressions of CSE, 3MST, and CAT in vivo [11,12,32] and in human UAEC in vitro [17]. In this study, $\mathrm{NaHS}$ was used as a source of $\mathrm{H}_{2} \mathrm{~S}$. In aqueous solution, $\mathrm{NaHS}$ dissociates to $\mathrm{Na}^{+}$and $\mathrm{HS}^{-}$, and $\mathrm{HS}^{-}$associates with $\mathrm{H}^{+}$to produce $\mathrm{H}_{2} \mathrm{~S}$. In neutral solution, one-third of $\mathrm{NaHS}$ exists as $\mathrm{H}_{2} \mathrm{~S}$, and the remaining two-thirds are present as $\mathrm{HS}^{-}$[52]. Thus, the solution of $\mathrm{H}_{2} \mathrm{~S}$ is about $\approx 66 \%$ of the original concentration of $\mathrm{NaHS}$ [53]. The liberation of $<1 \mathrm{mM}$ $\mathrm{Na}^{+}$from NaHS is negligible since the bath solution contained $145 \mathrm{mM} \mathrm{Na}^{+}$. The concentrations of $\mathrm{NaSH}$ used in this study ranged from 1 to $1000 \mu \mathrm{M}$, which did not change the $\mathrm{pH}$ of the buffered solution. The concentration of $\mathrm{NaSH}$ used in most of the experiments was $100 \mu \mathrm{M}$, equivalent to $\approx 60 \mu \mathrm{M} \mathrm{H}_{2} \mathrm{~S}$, which is close to the physiological plasma levels (less than $\approx 50 \mu \mathrm{M}$ ) of $\mathrm{H}_{2} \mathrm{~S}$ in humans [51]. Our data show that addition of $100 \mu \mathrm{M} \mathrm{NaSH}$ significantly activated $\mathrm{BK}_{\mathrm{Ca}}$ channels in hUASMC and dilated human UA rings in vitro, showing that $\mathrm{H}_{2} \mathrm{~S}$ is a physiological UA dilator.

Activation of $\mathrm{K}_{\text {ATP }}$ channels was the first mechanism that has been shown to mediate $\mathrm{H}_{2} \mathrm{~S}$-induced vasodilation in rat mesentery artery [19], which has been confirmed by many follow-up studies in other vessels $[36,47,48]$. However, activation of $\mathrm{K}_{\mathrm{ATP}}$ accounts for no more than half of the effect of $\mathrm{H}_{2} \mathrm{~S}$ to relax most vessels [54]. Likewise, opening of $\mathrm{BK}_{\mathrm{Ca}}$ channels results in $\mathrm{K}^{+}$efflux, causing membrane hyperpolarization of vascular SMC as a key mechanism for vasodilation [40]. UA BK $\mathrm{Ca}$ activity increases in pregnant sheep [55]. Local infusion of TEA to block $\mathrm{BK}_{\mathrm{Ca}}$ channels abolishes 
pregnancy-induced UA dilation in vitro [27] and inhibits pregnancy-associated uterine blood flow in vivo [28-30], while local infusion of glibenclamide to block the $\mathrm{K}_{\text {ATP }}$ channels does not significantly affect baseline pregnancy-associated uterine blood flow [20]. Consistently, we did not observe a significant effect of $\mathrm{H}_{2} \mathrm{~S}$ on $\mathrm{K}_{\text {ATP }}$ channels in hUASMC. Why $\mathrm{H}_{2} \mathrm{~S}$, unlike other systemic SMCs, does not activate $\mathrm{K}_{\mathrm{ATP}}$ channels in hUASMC warrants further elucidation. Nonetheless, our current data, along with data from in vivo studies using blockers of various $\mathrm{K}^{+}$channels to determining their role in pregnancy-associated rise in uterine blood flow $[20,28,30]$, suggest that activation of $\mathrm{SM} \mathrm{BK} \mathrm{Ca}_{\text {a }}$ channels is important for mediating $\mathrm{H}_{2} \mathrm{~S}$-induced UA dilation.

$\mathrm{BK}_{\mathrm{Ca}}$ channels, also known as $\mathrm{BK} / \mathrm{MaxiK} / \mathrm{Slo1} / \mathrm{K}_{\mathrm{Ca}} 1.1$ channels, are $\mathrm{K}^{+}$channels of largest single-channel conductance $(\approx 200-300 \mathrm{pS})$ [55]. The essential structure of $\mathrm{BK}_{\mathrm{Ca}}$ channels consist of the $\alpha$-ubunit and can be complemented with the regulatory subunits, including the $\beta$ isoforms (1-4) and $\gamma$ isoforms (1-4) [56,57]. The $\beta 1$ subunit is essential for increasing voltage sensitivity when intracellular free $\mathrm{Ca}^{2+}$ is beyond $1 \mu \mathrm{M}[22,58]$. The $\gamma 1-\gamma 4$ are auxiliary subunits that greatly modify channel activity in mammalian cells $[25,26,59-61]$. The expression and their physiological and pathological functions of $\mathrm{SM} \mathrm{BK} \mathrm{Ca}_{\mathrm{C}}$ channels have been well studied in other tissues in mammalians [62], but their distribution and function remains to be understudied in UA smooth muscle cells (UASMC). Previous studies have shown SM expression of $\alpha$ and $\beta 1$ [63] and $\gamma 1$ [31] subunits in UA; the $\alpha$ subunit is constitutively expressed and the $\beta 1$ and $\gamma 1$ subunits are significantly upregulated in pregnancy $[31,55]$. Herein, we show the expressions of $\alpha, \beta 1, \beta 3, \beta 4$, and $\gamma 1-3$, but not $\beta 2$ and $\gamma 4$, mRNAs, and $\beta 1$ and $\gamma 1$ and $\gamma 3$ proteins in hUA and cultured hUASMC. Which subunit(s) of these isoforms are responsible for the $\mathrm{H}_{2}$ S-induced $\mathrm{BK}_{\mathrm{Ca}}$ activity in hUASMC? Our current study did not provide any data to address this important question; however, $\beta 1$-containing $\mathrm{BK}_{\mathrm{Ca}}$ channels are sensitive to IBTX and low concentration of TEA $[22,64]$; the similar pharmacological properties with IBTX and TEA obtained in this study has implicated a functional role of $\beta 1$ subunit in $\mathrm{H}_{2} \mathrm{~S}$-induced $\mathrm{BK}_{\mathrm{Ca}}$ activity in hUASMC, consistent with previous studies showing that $\beta 1$ subunits are upregulated and are important for increasing $S M B K_{C a}$ activity in the UA in response to estrogen stimulation and during pregnancy $[55,65]$. The $\gamma 1$ subunit containing $\mathrm{BK}_{\mathrm{Ca}}$ channels are featured by the $\approx 120 \mathrm{mV}$ leftward shift at 0 and elevated cytosolic $\mathrm{Ca}^{2+}$, which facilitates $\mathrm{BK}_{\mathrm{Ca}}$ channel activity [22]; the $\gamma 3$ is less studied but also related to $\mathrm{Ca}^{2+}$ sensitivity of the channel [25]. $\gamma 1$ subunit is upregulated sevenfold in mouse UA in pregnancy [31]. Future studies are warranted to delineate whether they are involved in the $\mathrm{H}_{2} \mathrm{~S}$-induced UASMC BK $\mathrm{Ca}$ activity since $\gamma 1$ and $\gamma 3$ proteins are highly expressed in hUA and retained in hUASMC in culture.

How does $\mathrm{H}_{2} \mathrm{~S}$ activate $\mathrm{BK}_{\mathrm{Ca}}$ channels in hUASMC? With $\mathrm{BK}_{\mathrm{Ca}}$ channels being $\mathrm{Ca}^{2+}$-activated and voltage-dependent ion channels, activation requires either elevation of intracellular $\mathrm{Ca}^{2+}$ or depolarization of cell membrane [66]. The free intracellular $\mathrm{Ca}^{2+}$ concentration under resting conditions is $\approx 150 \mathrm{nM}$, although it is oscillating in some cells, and can increase as high as $500 \mathrm{nM}$ [67]. In addition, $\mathrm{Ca}^{2+}$ concentrations in the vicinity of $\mathrm{BK}_{\mathrm{Ca}}$ channels after influx through $\mathrm{Ca}^{2+}$ channels are between 4 and $30 \mu \mathrm{M}$ [68], which are dramatically higher compared to average cytoplasmic free internal $\mathrm{Ca}^{2+}$ concentrations. Free internal $\mathrm{Ca}^{2+}$ concentrations used in our experiments are within this range. In resistance-sized cerebral arteries, ryanodine receptor-sensitive $\mathrm{Ca}^{2+}$ sparks in sarcoplasmic reticulum (SR) activate $\mathrm{BK}_{\mathrm{Ca}}$ channels [69], while in the resting state of cerebral artery activation of $\mathrm{BK}_{\mathrm{Ca}}$ channels relies on $\mathrm{Ca}^{2+}$ influx through L-type voltage-dependent calcium channels (LTCC) [70]; however, this is not the case in coronary or mesenteric arteries, indicating that different mechanisms for $\mathrm{BK}_{\mathrm{Ca}}$ channel activation varies among vessels from different vascular beds. In hUASMC, blockade of LTCC using nifedipine does not affect $\mathrm{H}_{2} \mathrm{~S}$-induced $\mathrm{BK}_{\mathrm{Ca}}$ activity recorded by whole-cell patch clamp, suggesting LTCC-mediated $\mathrm{Ca}^{2+}$ influx is not involved. Similar results were also obtained with 0 free $\mathrm{Ca}^{2+}$ bath solution containing EGTA, indicating that $\mathrm{H}_{2} \mathrm{~S}$-induced $\mathrm{BK}_{\mathrm{Ca}}$ activity is independent of extracellular $\mathrm{Ca}^{2+}$, sharing similar properties with the $\mathrm{H}_{2} \mathrm{~S}$-responsive $\mathrm{BK}_{\mathrm{Ca}}$ channels in rat pituitary tumor cells [71]. In ovine UASMC, recent studies have shown that ryanodine-receptor sensitive $\mathrm{Ca}^{2+}$ sparks are important for pregnancy and estrogen stimulation of $\mathrm{BK}_{\mathrm{Ca}}$ channel activity [72]. In rat mesenteric arteries, $\mathrm{H}_{2} \mathrm{~S}$-induced vasodilation requires activation of endothelial $\mathrm{BK}_{\mathrm{Ca}}$ channels and 
smooth muscle $\mathrm{Ca}^{2+}$ sparks [21]. Thus, future studies are needed to determine if SR $\mathrm{Ca}^{2+}$ sparks mediate activation of the $\mathrm{H}_{2} \mathrm{~S}$-induced $\mathrm{BK}_{\mathrm{Ca}}$ channels in UASMC.

Apart from $\mathrm{Ca}^{2+}$ and voltage, many other mechanisms are also involved in regulating $\mathrm{BK}_{\mathrm{Ca}}$ channel activity, including phosphorylation by protein kinases such as protein kinase A (PKA), PKG, and PKC; PKA and PKG activate $\mathrm{BK}_{\mathrm{Ca}}$ channels through modulating the channel kinetics, while PKC shows an inhibitory manner on the channels [66]. In the present study, we show that NaHS modulates $\mathrm{BK}_{\mathrm{Ca}}$ channels directly by using outside-out single-channel patch recording. In the whole-cell patch recording mode, NaHS may modulate $\mathrm{BK}_{\mathrm{Ca}}$ channel activity indirectly through protein kinase-mediated phosphorylation. However, this idea needs to be further explored. In addition, direct sulfhydrating proteins in reactive cysteines has been recently recognized to be a major mechanism for $\mathrm{H}_{2} \mathrm{~S}$ to elicit its biological functions [73]. Direct sulfyhydration of Kir 6.1 on C43 has been shown to be a key mechanism for $\mathrm{H}_{2} \mathrm{~S}$-induced $\mathrm{K}_{\text {ATP }}$ channel activation [74]. In this study, the $\mathrm{H}_{2} \mathrm{~S}$-response $\mathrm{BK}_{\mathrm{Ca}}$ channel was found to be sensitive to DTT, which completely prevents protein cysteine modifications including sulfhydration [73]. Thus, this mechanism is highly likely involved in $\mathrm{H}_{2} \mathrm{~S}$-induced $\mathrm{BK}_{\mathrm{Ca}}$ channel activation in hUASMC, although detailed mechanisms around sulfhydration in terms of which subunit(s) and on which specific cysteine(s) are involved are still to be determined.

\section{Conclusions}

Altogether, we have shown herein that functional $\mathrm{BK}_{\mathrm{Ca}}$ channels are present in human UASMC, which can at least partially mediate the vascular relaxation effects of $\mathrm{H}_{2} \mathrm{~S}$ in human UA in vitro. However, it is necessary to point out that research in $\mathrm{H}_{2} \mathrm{~S}$ in uterine hemodynamics is still at a very early stage. Future studies are warranted to address many important questions so that a physiological and pathophysiological role of $\mathrm{H}_{2} \mathrm{~S}$ and the underlying mechanisms in uterine hemodynamic regulation can be delineated, pertaining to normal pregnancy and hypertension-related pregnancy complications such as preeclampsia.

Author Contributions: Y.L. and D.-b.C. conceived the idea and wrote the paper. Y.L. performed the experiments and analyzed the data. J.B. collected data. Y.-h.Y. contributed resources. N.H. contributed resources, supervised patch clamp, and edited the paper. D.-b.C. managed the resources and funding, and finalized the paper. All authors have read and agreed to the published version of the manuscript.

Funding: The present study was supported in part by National Institutes of Health (NIH) grants HL70562, HD097498, and HD102451 (to D.-b.C.). The content is solely the responsibility of the authors and does not necessarily reflect the official views of the NIH.

Acknowledgments: The authors thank all the volunteers for donating their removed uterus and the attending physicians at the University of California Irvine Medical Center for their assistance in tissue collection.

Conflicts of Interest: The authors declare no conflict of interest.

\section{References}

1. Greiss, F.C. Uterine blood flow during pregnnacy. $M C V$ Q. 1972, 8, 52-60.

2. Thornburg, K.L.; Jacobson, S.L.; Giraud, G.D.; Morton, M.J. Hemodynamic changes in pregnancy. Semin. Perinatol. 2000, 24, 11-14. [CrossRef]

3. Osol, G.; Mandala, M. Maternal uterine vascular remodeling during pregnancy. Physiology 2009, 24, 58-71. [CrossRef] [PubMed]

4. Barker, D.J. Intrauterine programming of adult disease. Mol. Med. Today 1995, 1, 418-423. [CrossRef]

5. Romero, R.; Dey, S.K.; Fisher, S.J. Preterm labor: One syndrome, many causes. Science 2014, 345, 760-765. [CrossRef]

6. Kimura, T.; Yoshida, Y.; Toda, N. Mechanisms of relaxation induced by prostaglandins in isolated canine uterine arteries. Am. J. Obstet. Gynecol. 1992, 167, 1409-1416. [CrossRef]

7. Magness, R.R.; Shaw, C.E.; Phernetton, T.M.; Zheng, J.; Bird, I.M. Endothelial vasodilator production by uterine and systemic arteries. II. Pregnancy effects on NO synthase expression. Am. J. Physiol. 1997, 272, H1730-H17340. [CrossRef] 
8. Gokina, N.I.; Kuzina, O.Y.; Vance, A.M. Augmented EDHF signaling in rat uteroplacental vasculature during late pregnancy. Am. J. Physiol. Heart Circ. Physiol. 2010, 299, H1642-H1652. [CrossRef]

9. Naden, R.P.; Iliya, C.A.; Arant, B.S., Jr.; Gant, N.F., Jr.; Rosenfeld, C.R. Hemodynamic effects of indomethacin in chronically instrumented pregnant sheep. Am. J. Obstet. Gynecol. 1985, 151, 484-494. [CrossRef]

10. Rosenfeld, C.R.; Cox, B.E.; Roy, T.; Magness, R.R. Nitric oxide contributes to estrogen-induced vasodilation of the ovine uterine circulation. J. Clin. Investig. 1996, 98, 2158-2166. [CrossRef]

11. Lechuga, T.J.; Qi, Q.R.; Magness, R.R.; Chen, D.B. Ovine uterine artery hydrogen sulfide biosynthesis in vivo: Effects of ovarian cycle and pregnancy. Biol. Reprod. 2019, 100, 1630-1636. [CrossRef] [PubMed]

12. Sheibani, L.; Lechuga, T.J.; Zhang, H.; Hameed, A.; Wing, D.A.; Kumar, S.; Rosenfeld, C.R.; Chen, D.B. Augmented $\mathrm{H}_{2} \mathrm{~S}$ production via cystathionine-beta-synthase upregulation plays a role in pregnancy-associated uterine vasodilation. Biol. Reprod. 2017, 96, 664-672. [CrossRef]

13. Bai, J.; Qi, Q.R.; Li, Y.; Day, R.; Makhoul, J.; Magness, R.R.; Chen, D.B. Estrogen receptors and estrogen-induced uterine vasodilation in pregnancy. Int. J. Mol. Sci. 2020, 21, 4349. [CrossRef] [PubMed]

14. Kimura, H. Hydrogen sulfide and polysulfides as biological mediators. Molecules 2014, 19, 16146-16157. [CrossRef]

15. Yang, G.; Wu, L.; Jiang, B.; Yang, W.; Qi, J.; Cao, K.; Meng, Q.; Mustafa, A.K.; Mu, W.; Zhang, S.; et al. $\mathrm{H}_{2} \mathrm{~S}$ as a physiologic vasorelaxant: Hypertension in mice with deletion of cystathionine gamma-lyase. Science 2008, 322, 587-590. [CrossRef]

16. Papapetropoulos, A.; Pyriochou, A.; Altaany, Z.; Yang, G.; Marazioti, A.; Zhou, Z.; Jeschke, M.G.; Branski, L.K.; Herndon, D.N.; Wang, R.; et al. Hydrogen sulfide is an endogenous stimulator of angiogenesis. Proc. Natl. Acad. Sci. USA 2009, 106, 21972-21977. [CrossRef]

17. Zhang, H.-H.; Chen, J.C.; Sheibani, L.; Lechuga, T.J.; Chen, N.-B. Pregnancy Augments VEGF-Stimulated In Vitro Angiogenesis and Vasodilator (NO and H2S) Production in Human Uterine Artery Endothelial Cells. J. Clin. Endocrinol. Metab. 2017, 102, 2382-2393. [CrossRef]

18. Tang, G.; Wu, L.; Liang, W.; Wang, R. Direct Stimulation of KATP Channels by Exogenous and Endogenous Hydrogen Sulfide in Vascular Smooth Muscle Cells. Mol. Pharmacol. 2005, 68, 1757-1764. [CrossRef]

19. Zhao, W.; Zhang, J.; Lu, Y.; Wang, R. The vasorelaxant effect of H2S as a novel endogenous gaseous KATP channel opener. EMBO J. 2001, 20, 6008-6016. [CrossRef]

20. Xiao, D.; Longo, L.D.; Zhang, L. Role of KATP and L-type $\mathrm{Ca}^{2+}$ channel activities in regulation of ovine uterine vascular contractility: Effect of pregnancy and chronic hypoxia. Am. J. Obstet. Gynecol. 2010, 203, 596.e6-596.e12. [CrossRef]

21. Jackson-Weaver, O.; Osmond, J.M.; Riddle, M.A.; Naik, J.S.; Bosc, L.V.G.; Walker, B.R.; Kanagy, N.L. Hydrogen sulfide dilates rat mesenteric arteries by activating endothelial large-conductance $\mathrm{Ca}^{2+}$-activated $\mathrm{K}^{+}$channels and smooth muscle $\mathrm{Ca}^{2+}$ sparks. Am. J. Physiol. Circ. Physiol. 2013, 304, H1446-H1454. [CrossRef] [PubMed]

22. Gonzalez-Perez, V.; Lingle, C.J. Regulation of BK Channels by Beta and Gamma Subunits. Annu. Rev. Physiol. 2019, 81, 113-137. [CrossRef] [PubMed]

23. Krishnamoorthy-Natarajan, G.; Koide, M. BK Channels in the Vascular System. Int. Rev. Neurobiol. 2016, 128, 401-438. [CrossRef]

24. Brayden, J.E.; Nelson, M.T. Regulation of arterial tone by activation of calcium-dependent potassium channels. Science 1992, 256, 532-535. [CrossRef]

25. Yan, J.; Aldrich, R.W. BK potassium channel modulation by leucine-rich repeat-containing proteins. Proc. Natl. Acad. Sci. USA 2012, 109, 7917-7922. [CrossRef]

26. Yan, J.; Aldrich, R.W. LRRC26 auxiliary protein allows BK channel activation at resting voltage without calcium. Nature 2010, 466, 513-516. [CrossRef]

27. Hu, X.Q.; Dasgupta, C.; Chen, M.; Xiao, D.; Huang, X.; Han, L.; Yang, S.; Xu, Z.; Zhang, L. Pregnancy reprograms large-conductance $\mathrm{Ca}^{2+}$-activated $\mathrm{K}^{+}$channel in uterine arteries: Roles of ten-eleven translocation methylcytosine dioxygenase 1-mediated active demethylation. Hypertension 2017, 69, 1181-1191. [CrossRef] [PubMed]

28. Rosenfeld, C.R.; Cornfield, D.N.; Roy, T. $\mathrm{Ca}^{2+}$-activated $\mathrm{K}^{+}$channels modulate basal and E2beta-induced rises in uterine blood flow in ovine pregnancy. Am. J. Physiol. Heart Circ. Physiol. 2001, 281, H422-H431. [CrossRef] 
29. Rosenfeld, C.R.; Liu, X.T.; DeSpain, K. Pregnancy modifies the large conductance $\mathrm{Ca}^{2+}$-activated $\mathrm{K}^{+}$channel and cGMP-dependent signaling pathway in uterine vascular smooth muscle. Am. J. Physiol. Heart Circ. Physiol. 2009, 296, H1878-H1887. [CrossRef]

30. Rosenfeld, C.R.; Roy, T.; DeSpain, K.; Cox, B.E. Large-conductance $\mathrm{Ca}^{2+}$-dependent $\mathrm{K}^{+}$channels regulate basal uteroplacental blood flow in ovine pregnancy. J. Soc. Gynecol. Investig. 2005, 12, 402-408. [CrossRef]

31. Lorca, R.A.; Wakle-Prabagaran, M.; Freeman, W.E.; Pillai, M.K.; England, S.K. The large-conductance voltageand $\mathrm{Ca}^{2+}$-activated $\mathrm{K}^{+}$channel and its gamma1-subunit modulate mouse uterine artery function during pregnancy. J. Physiol. 2018, 596, 1019-1033. [CrossRef] [PubMed]

32. Lechuga, T.J.; Zhang, H.H.; Sheibani, L.; Karim, M.; Jia, J.; Magness, R.R.; Rosenfeld, C.R.; Chen, D.B. Estrogen replacement therapy in ovariectomized nonpregnant ewes stimulates uterine artery hydrogen sulfide biosynthesis by selectively up-regulating cystathionine beta-synthase expression. Endocrinology 2015, 156, 2288-2298. [CrossRef] [PubMed]

33. Greene, D.L.; Kang, S.; Hoshi, N. XE991 and linopirdine are state-dependent inhibitors for Kv7/KCNQ channels that favor activated single subunits. J. Pharmacol. Exp. Ther. 2017, 362, 177-185. [CrossRef] [PubMed]

34. Kay, H.Y.; Greene, D.L.; Kang, S.; Kosenko, A.; Hoshi, N. M-current preservation contributes to anticonvulsant effects of valproic acid. J. Clin. Investig. 2015, 125, 3904-3914. [CrossRef] [PubMed]

35. Pallotta, B.S.; Magleby, K.L.; Barrett, J.N. Single channel recordings of Ca2+-activated $\mathrm{K}^{+}$currents in rat muscle cell culture. Nature 1981, 293, 471-474. [CrossRef] [PubMed]

36. Zhao, W.; Wang, R. H(2)S-induced vasorelaxation and underlying cellular and molecular mechanisms. Am. J. Physiol. Heart Circ. Physiol. 2002, 283, H474-H480. [CrossRef]

37. Hu, X.Q.; Dasgupta, C.; Xiao, D.; Huang, X.; Yang, S.; Zhang, L. MicroRNA-210 targets ten-eleven translocation methylcytosine dioxygenase 1 and suppresses pregnancy-mediated adaptation of large conductance $\mathrm{Ca}^{2+}$-activated $\mathrm{K}^{+}$channel expression and function in ovine uterine arteries. Hypertension 2017, 70, 601-612. [CrossRef]

38. Nelson, M.T.; Quayle, J.M. Physiological roles and properties of potassium channels in arterial smooth muscle. Am. J. Physiol. 1995, 268, C799-C822. [CrossRef]

39. Wang, R. Physiological implications of hydrogen sulfide: A whiff exploration that blossomed. Physiol. Rev. 2012, 92, 791-896. [CrossRef]

40. $\mathrm{Hu}, \mathrm{X} . \mathrm{Q}$; Zhang, L. Function and regulation of large conductance $\mathrm{Ca}^{2+}$-activated $\mathrm{K}^{+}$channel in vascular smooth muscle cells. Drug Discov. Today 2012, 17, 974-987. [CrossRef]

41. Salkoff, L.; Butler, A.; Ferreira, G.; Santi, C.; Wei, A. High-conductance potassium channels of the SLO family. Nat. Rev. Neurosci. 2006, 7, 921-931. [CrossRef] [PubMed]

42. Wang, R.; Wu, L. The chemical modification of KCa channels by carbon monoxide in vascular smooth muscle cells. J. Biol. Chem. 1997, 272, 8222-8226. [CrossRef] [PubMed]

43. Tang, X.D.; Daggett, H.; Hanner, M.; Garcia, M.L.; McManus, O.B.; Brot, N.; Weissbach, H.; Heinemann, S.H.; Hoshi, T. Oxidative regulation of large conductance calcium-activated potassium channels. J. Gen. Physiol. 2001, 117, 253-274. [CrossRef] [PubMed]

44. DiChiara, T.J.; Reinhart, P.H. Redox modulation of hslo $\mathrm{Ca}^{2+}$-activated $\mathrm{K}^{+}$channels. J. Neurosci. 1997, 17, 4942-4955. [CrossRef] [PubMed]

45. Erxleben, C.; Everhart, A.L.; Romeo, C.; Florance, H.; Bauer, M.B.; Alcorta, D.A.; Rossie, S.; Shipston, M.J.; Armstrong, D.L. Interacting effects of N-terminal variation and strex exon splicing on slo potassium channel regulation by calcium, phosphorylation, and oxidation. J. Biol. Chem. 2002, 277, 27045-27052. [CrossRef] [PubMed]

46. Gong, L.; Gao, T.M.; Huang, H.; Tong, Z. Redox modulation of large conductance calcium-activated potassium channels in CA1 pyramidal neurons from adult rat hippocampus. Neurosci. Lett. 2000, 286, 191-194. [CrossRef]

47. Jiang, B.; Tang, G.; Cao, K.; Wu, L.; Wang, R. Molecular mechanism for $\mathrm{H}_{2}$ S-induced activation of K(ATP) channels. Antioxid Redox Signal. 2010, 12, 1167-1178. [CrossRef]

48. Liang, G.H.; Adebiyi, A.; Leo, M.D.; McNally, E.M.; Leffler, C.W.; Jaggar, J.H. Hydrogen sulfide dilates cerebral arterioles by activating smooth muscle cell plasma membrane KATP channels. Am. J. Physiol. Heart Circ. Physiol. 2011, 300, H2088-H2095. [CrossRef] 
49. Materazzi, S.; Zagli, G.; Nassini, R.; Bartolini, I.; Romagnoli, S.; Chelazzi, C.; Benemei, S.; Coratti, A.; De Gaudio, A.R.; Patacchini, R. Vasodilator activity of hydrogen sulfide $\left(\mathrm{H}_{2} \mathrm{~S}\right)$ in human mesenteric arteries. Microvasc Res. 2017, 109, 38-44. [CrossRef]

50. Ariyaratnam, P.; Loubani, M.; Morice, A.H. Hydrogen sulphide vasodilates human pulmonary arteries: A possible role in pulmonary hypertension? Microvasc Res. 2013, 90, 135-137. [CrossRef]

51. Olson, K.R. Is hydrogen sulfide a circulating "gasotransmitter" in vertebrate blood? Biochim. Biophys. Acta 2009, 1787, 856-863. [CrossRef] [PubMed]

52. Beauchamp, R.O., Jr.; Bus, J.S.; Popp, J.A.; Boreiko, C.J.; Andjelkovich, D.A. A critical review of the literature on hydrogen sulfide toxicity. Crit. Rev. Toxicol. 1984, 13, 25-97. [CrossRef] [PubMed]

53. Reiffenstein, R.J.; Hulbert, W.C.; Roth, S.H. Toxicology of hydrogen sulfide. Annu. Rev. Pharmacol. Toxicol. 1992, 32, 109-134. [CrossRef] [PubMed]

54. Olson, K.R. The therapeutic potential of hydrogen sulfide: Separating hype from hope. Am. J. Physiol. Regul. Integr. Comp. Physiol. 2011, 301, R297-R312. [CrossRef]

55. Hu, X.Q.; Xiao, D.; Zhu, R.; Huang, X.; Yang, S.; Wilson, S.; Zhang, L. Pregnancy upregulates large-conductance $\mathrm{Ca}^{2+}$-activated $\mathrm{K}^{+}$channel activity and attenuates myogenic tone in uterine arteries. Hypertension 2011, 58, 1132-1139. [CrossRef]

56. Toro, L.; Li, M.; Zhang, Z.; Singh, H.; Wu, Y.; Stefani, E. MaxiK channel and cell signalling. Pflugers Arch. 2014, 466, 875-886. [CrossRef]

57. Meera, P.; Wallner, M.; Song, M.; Toro, L. Large conductance voltage- and calcium-dependent $\mathrm{K}^{+}$channel, a distinct member of voltage-dependent ion channels with seven N-terminal transmembrane segments (S0-S6), an extracellular N terminus, and an intracellular (S9-S10) C terminus. Proc. Natl. Acad. Sci. USA 1997, 94, 14066-14071. [CrossRef]

58. Meera, P.; Wallner, M.; Jiang, Z.; Toro, L. A calcium switch for the functional coupling between alpha (hslo) and beta subunits (Kv,cabeta) of maxi K channels. FEBS Lett. 1996, 385, 127-128. [CrossRef]

59. Marty, A.; Tan, Y.P.; Trautmann, A. Three types of calcium-dependent channel in rat lacrimal glands. J. Physiol. 1984, 357, 293-325. [CrossRef]

60. Ransom, C.B.; Liu, X.; Sontheimer, H. BK channels in human glioma cells have enhanced calcium sensitivity. Glia 2002, 38, 281-291. [CrossRef]

61. Gessner, G.; Schonherr, K.; Soom, M.; Hansel, A.; Asim, M.; Baniahmad, A.; Derst, C.; Hoshi, T.; Heinemann, S.H. BKCa channels activating at resting potential without calcium in LNCaP prostate cancer cells. J. Membr. Biol. 2005, 208, 229-240. [CrossRef] [PubMed]

62. Dopico, A.M.; Bukiya, A.N.; Jaggar, J.H. Calcium- and voltage-gated BK channels in vascular smooth muscle. Pflugers Arch. 2018, 470, 1271-1289. [CrossRef] [PubMed]

63. Rosenfeld, C.R.; Word, R.A.; DeSpain, K.; Liu, X.T. Large conductance $\mathrm{Ca}^{2+}$-activated $\mathrm{K}^{+}$channel channels contribute to vascular function in nonpregnant human uterine arteries. Reprod. Sci. 2008, 15, 651-660. [CrossRef] [PubMed]

64. Michelakis, E.D.; Reeve, H.L.; Huang, J.M.; Tolarova, S.; Nelson, D.P.; Weir, E.K.; Archer, S.L. Potassium channel diversity in vascular smooth muscle cells. Can. J. Physiol. Pharmacol. 1997, 75, 889-897. [CrossRef] [PubMed]

65. Nagar, D.; Liu, X.T.; Rosenfeld, C.R. Estrogen regulates $\left\{\right.$ beta\}1-subunit expression in $\mathrm{Ca}^{2+}$-activated $\mathrm{K}^{+}$ channel in arteries from reproductive tissues. Am. J. Physiol. Heart Circ. Physiol. 2005, 289, H1417-H1427. [CrossRef] [PubMed]

66. Schubert, R.; Nelson, M.T. Protein kinases: Tuners of the BKCa channel in smooth muscle. Trends Pharmacol. Sci. 2001, 22, 505-512. [CrossRef]

67. Bagur, R.; Hajnoczky, G. Intracellular $\mathrm{Ca}^{2+}$ sensing: Its role in calcium homeostasis and signaling. Mol. Cell 2017, 66, 780-788. [CrossRef]

68. Perez, G.J.; Bonev, A.D.; Nelson, M.T. Micromolar $\mathrm{Ca}^{2+}$ from sparks activates $\mathrm{Ca}^{2+}$-sensitive $\mathrm{K}^{+}$channels in rat cerebral artery smooth muscle. Am. J. Physiol. Cell Physiol. 2001, 281, C1769-C1775. [CrossRef]

69. Nelson, S.H.; Steinsland, O.S.; Johnson, R.L.; Suresh, M.S.; Gifford, A.; Ehardt, J.S. Pregnancy-induced alterations of neurogenic constriction and dilation of human uterine artery. Am. J. Physiol. 1995, 268, H1694-H1701. [CrossRef] 
70. Asano, M.; Masuzawa-Ito, K.; Matsuda, T.; Suzuki, Y.; Oyama, H.; Shibuya, M.; Sugita, K. Functional role of charybdotoxin-sensitive $\mathrm{K}^{+}$channels in the resting state of cerebral, coronary and mesenteric arteries of the dog. J. Pharmacol. Exp. Ther. 1993, 267, 1277-1285.

71. Sitdikova, G.F.; Weiger, T.M.; Hermann, A. Hydrogen sulfide increases calcium-activated potassium (BK) channel activity of rat pituitary tumor cells. Pflugers Arch. 2010, 459, 389-397. [CrossRef] [PubMed]

72. Hu, X.Q.; Song, R.; Romero, M.; Dasgupta, C.; Huang, X.; Holguin, M.A.; Williams, V.; Xiao, D.; Wilson, S.M.; Zhang, L. Pregnancy increases $\mathrm{Ca}^{2+}$ sparks/spontaneous transient outward currents and reduces uterine arterial myogenic tone. Hypertension 2019, 73, 691-702. [CrossRef] [PubMed]

73. Mustafa, A.K.; Gadalla, M.M.; Sen, N.; Kim, S.; Mu, W.; Gazi, S.K.; Barrow, R.K.; Yang, G.; Wang, R.; Snyder, S.H. $\mathrm{H}_{2} \mathrm{~S}$ signals through protein S-sulfhydration. Sci. Signal. 2009, 2, ra72. [CrossRef] [PubMed]

74. Mustafa, A.K.; Sikka, G.; Gazi, S.K.; Steppan, J.; Jung, S.M.; Bhunia, A.K.; Barodka, V.M.; Gazi, F.K.; Barrow, R.K.; Wang, R.; et al. Hydrogen sulfide as endothelium-derived hyperpolarizing factor sulfhydrates potassium channels. Circ. Res. 2011, 109, 1259-1268. [CrossRef]

Publisher's Note: MDPI stays neutral with regard to jurisdictional claims in published maps and institutional affiliations.

(C) 2020 by the authors. Licensee MDPI, Basel, Switzerland. This article is an open access article distributed under the terms and conditions of the Creative Commons Attribution (CC BY) license (http://creativecommons.org/licenses/by/4.0/). 